\title{
The Macrophage Phagocytic Receptor CD36 Promotes Fibrogenic Pathways on Removal of Apoptotic Cells during Chronic Kidney Injury
}

\author{
Subramaniam Pennathur, ${ }^{*}$ Katie Pasichnyk, ${ }^{\dagger}$ Nadia M. Bahrami, ${ }^{\dagger}$ Lixia Zeng, ${ }^{\star}$ Maria Febbraio, ${ }^{\ddagger}$ Ikuyo Yamaguchi, ${ }^{\dagger}$ and
} Daryl M. Okamura

From the Department of Internal Medicine, * University of Michigan, Ann Arbor, Michigan; the Seattle Children's Hospital Research Institute, ${ }^{\dagger}$ University of Washington, Seattle, Washington; and the Department of Dentistry, ${ }^{\ddagger}$ University of Alberta, Edmonton, Alberta, Canada

\author{
Accepted for publication \\ April 8, 2015. \\ Address correspondence to \\ Daryl M. Okamura, M.D., \\ Seattle Children's Research \\ Institute, Center for Develop- \\ mental Biology \& Regenerative \\ Medicine, 1900 Ninth Ave., \\ CS9-5, Seattle, WA 98101. \\ E-mail: daryl.okamura@ \\ seattlechildrens.org.
}

\begin{abstract}
The removal of apoptotic cells is an innate function of tissue macrophages; however, its role in disease progression is unclear. The present study was designed to investigate the role of macrophage CD36, a recognized receptor of apoptotic cells and oxidized lipids, in two models of kidney injury: unilateral ureteral obstruction (UU0) and ischemia reperfusion. To differentiate the macrophage CD36-specific effects in vivo, we generated CD36 chimeric mice by bone marrow transplantation and evaluated the two models. Fibrosis severity was substantially decreased after UUO with a corresponding decrease in matrix synthesis in macrophage CD36-deficient mice. Despite a reduction in fibrosis severity, a $56 \%$ increase in apoptotic cells was found without an increase in apoptotic effectors. In addition, a substantial reduction was observed in tumor necrosis factor- $\alpha$ and transforming growth factor$\beta 1$ mRNA levels and intracellular bioactive oxidized lipid levels in CD36-deficient macrophages. To validate the functional role of macrophage CD36, we performed unilateral ischemia reperfusion, followed by contralateral nephrectomy. Similarly, we found that the severity of fibrosis was reduced by $55 \%$ with a corresponding improvement in kidney function by $88 \%$ in macrophage CD36-deficient mice. Taken together, these data suggest that macrophage CD36 is a critical regulator of oxidative fibrogenic signaling and that CD36-mediated phagocytosis of apoptotic cells may serve as an important pathway in the progression of fibrosis. (Am J Pathol 2015, 185: 2232-2245; http:// dx.doi.org/10.1016/j.ajpath.2015.04.016)
\end{abstract}

Studies in various organ systems, including the kidney, provide strong evidence that macrophages control fibrosis progression and resolution. ${ }^{1-4}$ During both acute and chronic kidney injury, the interstitial macrophage population is heterogenous and polarized into distinct subsets. In vitro studies have dissected classically activated (M1) and alternatively activated (M2) macrophages on the basis of cytokine activation patterns as follows: M1 macrophages express proinflammatory cytokines such as IL-1 $\beta$, tumor necrosis factor (TNF) $\alpha$, and IL-6, whereas M2 macrophages suppress expression of the proinflammatory mediators. ${ }^{5}$ Studies in solid-organ injury suggest that this M2 population is further subdivided into reparative, regulatory, and profibrotic phenotypes. ${ }^{6-8}$ However, studies suggest that complex tissue microenvironments are not adequately mirrored by the M1/M2 paradigm and that macrophage activation is more versatile and dynamic in response to the surrounding milieu. $^{9-12}$ Therefore, further delineation of tissue macrophage phenotypes should be based on functional outcome during kidney injury.

Phagocytosis is an inherent function of tissue macrophages for the removal of apoptotic cells and cellular debris during acute and chronic injury; however, the implications of this

Supported by NIH grants 5 K08 DK073497(D.M.O.), 5 R03 DK083648 (D.M.O.), DK082841 (S.P.), DK081943 (S.P.), and DK89503 (S.P.) and the National Kidney Foundation Young Investigator award (D.M.O.).

Disclosures: None declared.

Portions of this work were presented as an abstract at the American Society of Pediatric Nephrology Annual Meeting, May 4-7, 2013, Washington, DC; and at the American Society of Nephrology 46th Annual Meeting, November 5-10, 2013, Atlanta, Georgia. 
Table 1 qPCR Primer Sequences

\begin{tabular}{lll}
\hline Gene/primer name & Forward & Reverse \\
\hline TNF & $5^{\prime}$-CATCTTCTCAAAATTCGAGTGACAA-3' & $5^{\prime}-$ TGGGAGTAGACAAGGTACAACCC-3' \\
TNFRSF1A & $5^{\prime}$-GCTGACCCTCTGCTCTACGAA-3' & $5^{\prime}-$ GCCATCCACCACAGCATACA-3' \\
BCl211 (Bim) & $5^{\prime}$-GTCCCGGTCCTCCAGTGGGT-3' & $5^{\prime}-$ GTGGTCTTCAGCCTCGCGGT-3' \\
BBC3 (PUMA) & $5^{\prime}$-CTGGACTGCCAGCCTTGCCC-3' & $5^{\prime}-$ GAAGGCGCACTGGGGACACC-3' \\
CYBB (Nox2) & $5^{\prime}$-GGGAGACTGGACGGAGGGGC-3' & $5^{\prime}-$ ATGCGTGTCCCTGCACAGCC-3' \\
Nox4 & $5^{\prime}$-CACCAAACACAGAAGCACAAG-3' & $5^{\prime}-$ AGAAAGCAAAGCAGGGTATCA-3' \\
Fibronectin & $5^{\prime}$-AGACTGCAGTGACCACCATTC-3' & $5^{\prime}-$ AATGTGTCCTTGAGAGCATAGAC-3' \\
Procollagen 1 & $5^{\prime}$-AGAAGTCTCAAGATGGTGGCCG-3' & $5^{\prime}-$ GGTCACGAACCACGTTAGCATC-3' \\
Procollagen 3 & $5^{\prime}$-CAGCTATGGCCCTCCTGATCTT-3' & $5^{\prime}-$ GTAATGTTCTGGGAGGCCCG-3' \\
GAPDH & $5^{\prime}$-ACTTTGTCAAGCTCATTTCC-3' & $5^{\prime}-$ TGCAGCGAACTTTATTGATG-3' \\
18S & $5^{\prime}$-GGTGAAATTCTTGGACCGGC-3' & $5^{\prime}-$ GACTTTGGTTTCCCGGAAGC-3' \\
\hline
\end{tabular}

qPCR, quantitative real-time PCR.

event on macrophage function during tissue remodeling and fibrosis are not known. ${ }^{13}$ When a cell undergoes apoptosis or necrosis, several damage-associated molecular patterns are expressed for recognition by a host of pattern recognition receptors on macrophages. ${ }^{14} \mathrm{CD} 36$ is a class B scavenger receptor expressed on the surface of several cell types, including macrophages, platelets, microvascular endothelial cells, and renal tubular cells. Although several in vitro studies have identified CD36 as an important macrophage receptor of apoptotic cell recognition and phagocytosis, few studies have examined its in vivo role during chronic injury. ${ }^{15-17}$ Our previous work demonstrated that CD36 is important in promoting fibrosis but did not differentiate the specific roles of CD36-bearing cells. ${ }^{18}$ Here, we hypothesized that macrophage CD36 plays a critical role in promoting fibrogenesis through oxidative and inflammatory pathways after kidney injury. The results of this study provide evidence that the CD36 receptor identifies a profibrotic M2 macrophage phenotype and suggests that CD36-dependent phagocytosis of apoptotic cells is an important step in fibrogenic signaling in chronic kidney disease progression.

\section{Materials and Methods}

\section{Experimental Design}

Three lines of CD36 chimeric mice were generated by bone marrow transplantation. Recipient $\mathrm{Cd}_{3} 6^{+/+}$littermate male mice, 8 to 10 weeks of age, were placed on antibiotic-treated water (Enrofloxacin/Baytril 2.27\%; 0.016\% final; Bayer, Wuppertal, Germany) for 3 to 5 days before irradiation and 14 days after irradiation. Recipient mice $\left(\mathrm{Cd} 36^{+/+}\right.$or $\mathrm{Cd} 36^{-/-}$; $\mathrm{CD} 36^{+/+}$and $\mathrm{CD} 36^{-/-}$, respectively, in this study) received 900 rads from a cesium $\gamma$ source (J.L. Shepherd Model MKI-30 Irradiator; J.L. Shepherd, San Fernando, CA) and were injected with $10^{7}$ donor cells $\left(\mathrm{CD} 36^{+/+}\right.$or $\left.\mathrm{CD} 36^{-/-}\right)$retroorbitally or via tail vein. We used two models of kidney injury on these chimeric mice to investigate the role of macrophage CD36 in fibrosis: unilateral ureteral obstruction (UUO) and ischemia reperfusion (IR) injury. Surgery was performed 8 to 10 weeks after irradiation. UUO was performed on chimeric mice as previously described ${ }^{18,19}$ ( $n=5$ to 8 per group), and they were sacrificed at 7 and 14 days after surgery. Mice received isoflurane anesthesia (5\% induction; $1 \%$ to $3 \%$ maintenance) in oxygen through a precision vaporizer (portable anesthesia machine; Molecular Imaging Products, Bend, OR).

Unilateral IR surgery was performed through a retroperitoneal, paraspinal incision and placement of a vascular clamp on the left renal pedicle for 28 minutes while mice $(n=8$ per group) were kept at a constant temperature of $37^{\circ} \mathrm{C}$ by using a rectal probe temperature controller (Braintree Scientific, Braintree, MA). Reperfusion was confirmed with release of the vascular clamp, and mice were given a $1-\mathrm{mL}$ intraperitoneal injection of warm saline at the conclusion of the procedure. On the unilateral IR mice only, a contralateral nephrectomy was performed 14 days after surgery through a retroperitoneal, paraspinal incision to allow for the evaluation of kidney function. Serum was obtained at 3 days and at sacrifice (14 days) after nephrectomy to analyze kidney function. Chimerism was determined by PCR on DNA from leukocytes in peripheral blood of chimeric mice obtained at sacrifice. Primers for the wild-type $C d 36$ allele are forward, 5'-CAGCTCATACATTGCTGTTTATGCATG-3'; reverse, 5'-GGTACAATCACAGTGTTTTCTACGTGG-3' (band size approximately $600 \mathrm{bp}$ ). The primers for the CD36-deficient allele include the wild-type forward primer and the reverse 5'-CGCTTCCTCGTGCTTTACGGTATC-3' (band size approximately $750 \mathrm{bp}$ ). All procedures were performed in accordance with the guidelines established by the NIH's Guide for the Care and Use of Laboratory Animals ${ }^{20}$ and approval of our Institute Animal Care and Use Committee. Contralateral and UUO kidneys were harvested and processed for RNA and protein extraction and histologic studies as previously described. ${ }^{18,19,21}$ Frozen tissue samples were stored at $-80^{\circ} \mathrm{C}$.

\section{Collagen Content}

Hydroxyproline content of kidney tissue (microgram of hydroxyproline per milligram of wet weight kidney section) was measured by acid hydrolysis of the tissue section by using procedures established in our laboratory. ${ }^{18,19,21}$ 


\section{Histologic Examination}

Immunohistochemical staining was performed on sections of paraffin-embedded tissue or cryosections of snap-frozen tissue by using procedures established in our laboratory with
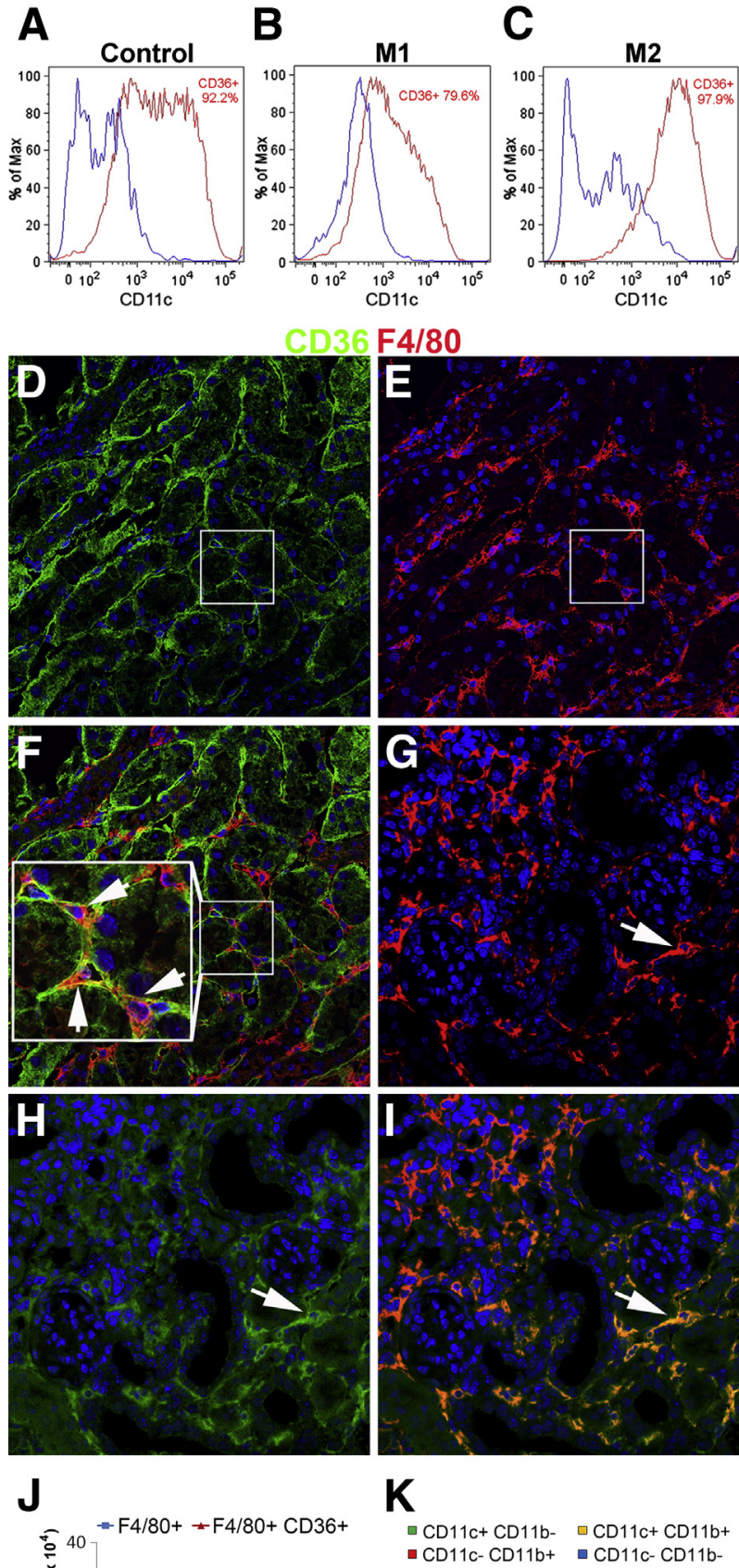

K
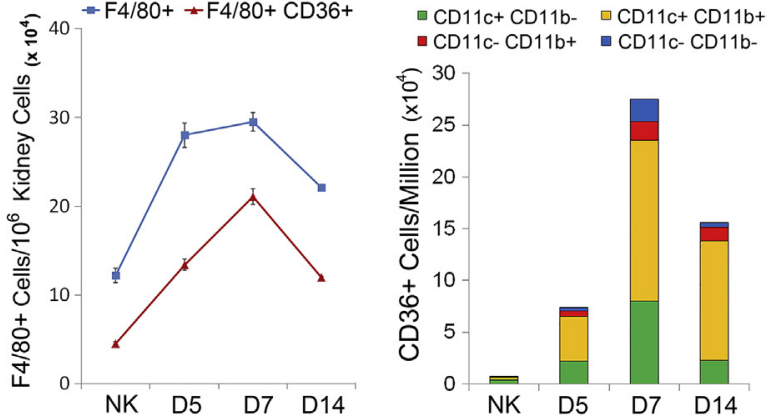

VECTASTAIN Elite ABC Kits (Vector Laboratories, Inc., Burlingame, CA) and AEC Substrate Chromogen K3464 (Dako Corp., Carpinteria, CA). Sections were blocked with Avidin/Biotin blocking kit (Vector Laboratories, Inc.). Terminal deoxynucleotidyl transferase-mediated dUTP nick-end labeling (TUNEL) staining was performed as previously described. ${ }^{21,22}$ Picrosirius red staining was performed as previously described. ${ }^{18,21}$ Periodic-acid Schiff stains were performed on paraffin sections by standard protocols. Tubular injury was analyzed on six to eight randomly selected periodic acid-Schiff-stained images. The following tubular injury scores were assigned, in a blinded manner (N.M.B., D.M.O.), based on the estimated percentage of area affected with tubular dilatation, tubular cell flattening, interstitial inflammation, and loss of intact tubular architecture in the field: $1(<10 \%), 2(10 \%$ to $25 \%), 3(26 \%$ to $50 \%), 4(51 \%$ to $75 \%)$, or $5(>75 \%)$. The primary antibody was reactive with Lipocalin 2 (Lcn2; rabbit anti-mouse Lcn2; Abcam, Cambridge, MA) on paraffin sections. Secondary antibodies were shown to be nonreactive with tissue sections stained without the primary antibody. Semiquantitative computer-assisted image analysis was performed on six to eight randomly selected $\times 400$-magnified images of slides from individual animals with Image-Pro Plus software version 7.0 (Mediatech, Herndon, VA). The investigators (N.M.B., D.M.O.) were blinded to the experimental groups at the time of analysis.

\section{Western Blot Analysis}

Protein was isolated from homogenized frozen kidney, and Western blot analysis was performed as previously described. ${ }^{18,19}$ The primary antibodies used were reactive with nuclear factor of $\kappa$ light polypeptide gene enhancer in B-cells inhibitor $\alpha$ (I $\kappa$ B- $\alpha$ ) and phosphorylated I $\mathrm{KB}-\alpha$ (rabbit anti-human I $\kappa \mathrm{B}-\alpha$ polyclonal and rabbit antihuman phospho IкB- $\alpha$ polyclonal; Cell Signaling Technology, Danvers, MA); Lyn kinase (rabbit anti-human Lyn kinase; Cell Signaling Technology); and c-Jun N-terminal

Figure 1 Scavenger receptor CD36 identifies a phagocytic M2 macrophage. Wild-type BMDMs were activated with M1 (LPS/IFN $\gamma$ ) or M2 (IL-4) stimuli. BMDMs ( $\left.\mathrm{CD} 45^{+} \mathrm{CD} 11 \mathrm{C}^{+}\right)$were analyzed for $\mathrm{CD} 36$ expression by FACS (blue $\mathrm{CD}_{6} 6^{-}$, red $\mathrm{CD}^{+} 6^{+}$) at baseline (A) and at M1 (B) and M2 (C) activation. Representative confocal images in normal kidneys: CD36 (green; D, boxed areas), F4/80 (red; E, boxed areas), and merged ( $F$, inset); arrows in inset indicate $\mathrm{CD}_{3}{ }^{+}$resident macrophages surrounding renal tubules. After UU0, a significant portion of the $\mathrm{F} 4 / 80^{+}$population $(\mathbf{G})$ are $\mathrm{CD}^{+} 6^{+}(\mathbf{H})$ and merged (I). Arrows indicate a subpopulation of $\mathrm{CD} 6^{+}$phagocytic macrophages (G-I). J: Graph summarizes FACS analysis of $\mathrm{CD} 45^{+} \mathrm{F} 4 / 80^{+}$subpopulations by $\mathrm{CD} 36$ expression. K: Graph summarizes FACS analysis of $\mathrm{CD} 45^{+} \mathrm{CD} 36^{+}$ subpopulations from UUO kidneys at day 5, 7, and 14 by the markers CD11b and CD11C (Supplemental Figure S2). Data are expressed as means \pm SEM. $n=4$ per group. Original magnification: $\times 400(\mathbf{D}-\mathbf{F})$. BMDM, bone marrowderived macrophage; Cy5.5, cyanine 5.5; FACS, fluorescent-activated cell sorting; IFN, interferon; LPS, lipopolysaccharide; M1, classically activated; M2, alternatively activated; NK, contralateral kidney; PerCP, peridinin chlorophyll; UU0, unilateral ureteral obstruction. 

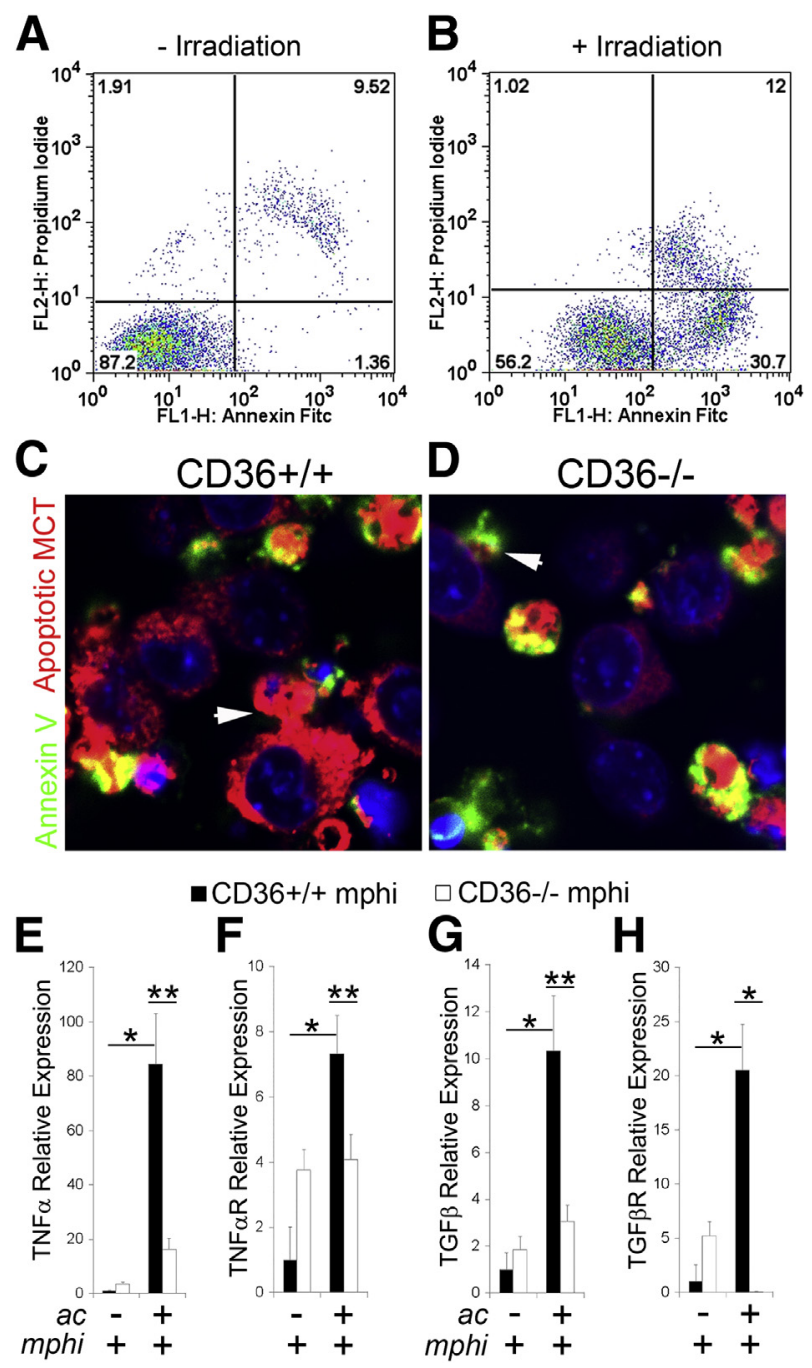

Figure 2 CD36-dependent apoptotic cell clearance activates fibrogenic pathways. Apoptotic tubular cells were generated by irradiating MCT cells. A and B: FACS analysis with Annexin $V$ and propidium iodide confirm latestage apoptosis in MCT cells. Mouse peritoneal TEMs were co-cultured with apoptotic MCT cells labeled with CellTracker (red). C: Arrow indicates CD36 ${ }^{+/+}$TEM engulfing Annexin $\mathrm{V}^{+}$MCT cells. D: Apoptotic cells are cleared at a reduced rate in $\mathrm{CD}_{3} 6^{-/-}$TEMs. Arrow indicates apoptotic cell bound to $\mathrm{CD}^{-/-}$TEMs but not engulfed. Semiquantitative real-time PCR was performed 24 hours after co-culture of TEMs and apoptotic MCT cells. Graphs summarize expression levels normalized to $18 \mathrm{~S}$ and GAPDH: TNF $\alpha$ (E), TNF $\alpha$ receptor 1 (F), TGF- $\beta 1(\mathbf{G})$, and TGF- $\beta 1$ receptor $(\mathbf{H})$. Comparison groups are $\mathrm{CD} 36^{+/+}$mphi only $(\mathrm{ac}-)$ versus $\mathrm{CD} 36^{+/+}$mphi with ac; and $\mathrm{CD} 36^{+/+}$mphi with ac versus $\mathrm{CD}^{-1-}$ mphi with ac. Data are expressed as means \pm SEM. $n=4$ per group; ${ }^{*} P<0.05,{ }^{* *} P<0.01$. Original magnification: $\times 800$ (C and D). ac, apoptotic cell; FACS, fluorescent-activated cell sorting; FITC, fluorescein isothiocyanate; MCT, mouse cortical tubular; mphi, TEM; TEM, thioglycollate-elicited macrophage; TGF, transforming growth factor; TNF, tumor necrosis factor.

kinase-2 (JNK2; goat anti-human JNK2; Santa Cruz Biotechnology, Santa Cruz, CA). The secondary antibodies were IR700Dye and IR800Dye (Rockland Immunochemicals Inc., Gilbertsville, PA). Protein bands were visualized and quantified with Odyssey (Li-Cor Biosciences, Lincoln, NE).

\section{Semi-qPCR}

Total RNA from frozen kidney tissue homogenate was obtained with the Maxwell 16 instrument (Promega, Madison, WI). Total RNA from isolated or cultured cells was obtained with the RNAqueous-4PCR Total RNA Isolation Kit (Ambion, Grand Island, NY). RNA samples were loaded on a Agilent RNA 6000 Nano Chip and analyzed in the Agilent 2100 Bioanalyzer (Agilent Technologies, Foster City, CA) for RNA concentration and quality; samples with RNA integrity numbers $>8.0$ were used for cDNA synthesis. First-strand cDNA was prepared from $1 \mu \mathrm{g}$ of total RNA by using the BioRad iScript cDNA Synthesis kit (Bio-Rad Laboratories, Hercules, CA). Semiquantitative real-time PCR (semi-qPCR) was performed as previously described. ${ }^{23,24}$ Semi-qPCR was performed according to the IQ SYBR Green Supermix kit methods (Bio-Rad Laboratories) by using primers listed in Table 1. Reactions were run in triplicate, and genes of interest were normalized to both $18 S$ (GenBank; http://www. ncbi.nlm. nih.gov/genbank; Accession number X00686.1) and GAPDH housekeeping genes. Data analysis was performed with the Pfaffl algorithm with the REST analysis software version 1.9.9 (Corbett Research Pty Ltd, Brisbane, Queensland, Australia).

\section{Macrophage Phagocytosis and Apoptotic Tubular Cells}

Apoptotic renal tubular cells were generated by irradiating immortalized murine proximal tubular cells with 2000 rads at $60 \%$ to $70 \%$ confluence in Dulbecco's modified Eagle's medium with $5 \%$ fetal calf serum (media) to induce apoptosis. Apoptosis was confirmed by Annexin V fluorescent-activated cell sorting analysis and DNA fragmentation assays. Thioglycollate-elicited macrophages (TEMs) were harvested 3 days after intraperitoneal injection of $2 \mathrm{~mL}$ of $3 \%$ thioglycollate (Fisher Scientific, Pittsburgh, PA) and cultured for 24 hours in media. TEMs were co-cultured with apoptotic murine proximal tubular cells ( 24 hours after irradiation) at a ratio of 3:1 (apoptotic cell/macrophage) in serum-free media (Opti-MEM; Invitrogen, Carlsbad, CA). After 4 hours cells were washed with phosphate-buffered saline to remove nonphagocytosed cells and were placed in media. After 24 hours cells were harvested and processed for total RNA, and semi-qPCR was performed.

\section{Interstitial Macrophage Isolation}

Mice were perfused with cold antioxidant buffer as previously described. ${ }^{18}$ Contralateral and UUO kidneys were placed on ice, digested with Liberase TL (Roche, Indianapolis, IN) with $1 \%$ DNase (Sigma-Aldrich, St. Louis, CA), then placed at $37^{\circ} \mathrm{C}$ for 10 minutes. Glomeruli were removed by passing cell suspension through a $40-\mu \mathrm{m}$ nylon filter. Mouse CD11b MicroBeads (Miltenyi Biotec, Auburn, CA) were added to single-cell suspension according to the manufacturer's protocol. CD $11 \mathrm{~b}^{+}$cells were isolated by positive selection by using the AutoMACS Pro (Miltenyi Biotec). 

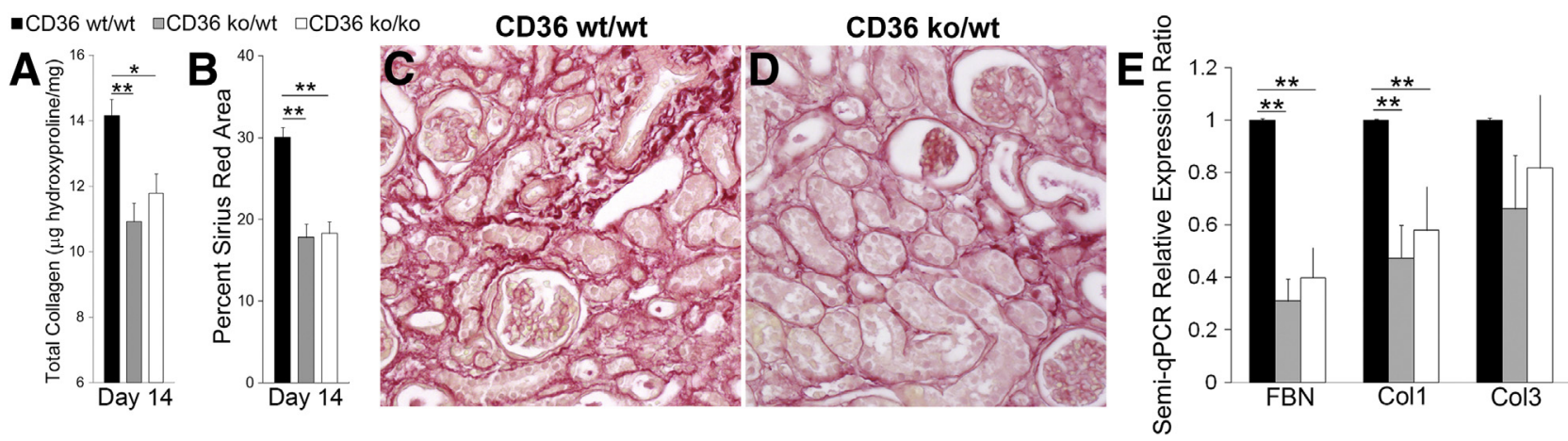

Figure 3 Macrophage CD36 is a profibrotic phenotype. A: Total kidney collagen content, measured with the hydroxyproline assay. B: The graph summarizes the results of picrosirius red ${ }^{+}$interstitial collagen quantification, analyzed by nested analysis of variance, with representative images (C and $\left.\mathbf{D}\right)$. E: The graph shows the results of analysis of kidney extracellular matrix mRNA levels, measured by semi-qPCR and normalized to two housekeeping genes, $18 S$ and GAPDH: FBN, Col1, and Col3. Data are expressed as means \pm SEM. $n=5$ to 6 per group. ${ }^{*} P<0.05,{ }^{* *} P<0.01$. Original magnification: $\times 400$ (C and D). Col1, procollagen I; Col3, procollagen III; FBN, fibronectin; K0, knockout; semi-qPCR, semiquantitative real-time PCR; wt, wild-type.

\section{Co-Immunoprecipitation Assay}

$\mathrm{CD}_{11 \mathrm{~b}^{+}}$interstitial kidney macrophages were isolated as described in the previous paragraph. Cells were immediately placed in $2 \mathrm{mmol} / \mathrm{L}$ Dithiobis(succinimidyl propionate) (Pierce Biotechnology, Waltham, MA), incubated for $30 \mathrm{mi}-$ nutes at room temperature, and placed in $20 \mathrm{mmol} / \mathrm{L}$ Tris $\mathrm{pH}$ 7.5 on ice. CD36 antibody (mouse anti-mouse CD36 IgA; Santa Cruz Biotechnology) was coupled to Dynabeads M-270 Epoxy (Invitrogen, Carlsbad, CA) according to the manufacturer's protocol. CD36 beads were incubated for 30 minutes at $4^{\circ} \mathrm{C}$ with $500 \mu \mathrm{g}$ of protein, washed, and eluted with coimmunoprecipitation proteins per protocol. Eluted proteins were loaded onto a $4 \%$ to $20 \%$ gradient SDS-PAGE gel (BioRad Laboratories) and transferred to a polyvinylidene difluoride membrane.

\section{Macrophage Activation}

Bone marrow was harvested from femurs and tibias of wild-type C57BL/6 mice and cultured in Petri dishes with Dulbecco's modified Eagle's medium and 10\% fetal calf serum, supplemented with $0.1 \mu \mathrm{g} / \mathrm{mL}$ macrophage colonystimulating factor (CSF1) for at least 6 days. Bone marrowderived macrophages (BMDMs) were used between 6 and 8 days. M1 stimulation was performed with lipopolysaccharide and interferon- $\gamma$. M2 stimulation was performed with IL-4. ${ }^{5}$ Peritoneal TEMs were obtained from CD $36^{+/+}$and CD $36^{-/-}$ mice and cultured for 24 hours in media, as described in Macrophage Phagocytosis and Apoptotic Tubular Cells, and stimulated with M1 or M2 cytokines. TEM plates were harvested after 24 hours of stimulation for total RNA. Each experiment was repeated in triplicate.

\section{Flow Cytometry}

Cells were stained per protocol with DAPI, phycoerythrincyanine 7-anti-CD45, phycoerythrin-anti-CD11b, peridinin chlorophyll-cyanine 5.5-anti-CD11c, fluorescein
isothiocyanate-anti-CD36, allophycocyanin-eFluor780-F4/80 from BD Sciences (San Jose, CA). Cells were blocked with FcR blocker. Leukocytes were identified and gated on the basis of their positive CD45 expression. Data were acquired on the LSR II flow cytometer (BD Biosciences) and analyzed with FlowJo software version 9 (TreeStar, Inc., Ashland, OR).

\section{Kidney Function}

Serum was analyzed for blood urea nitrogen by using the Urea Nitrogen (BUN) Reagent Set kit (Teco Diagnostics, Anaheim, CA). Samples were processed according to the manufacturer's protocol. Serum was analyzed for creatinine content by using the Mouse Creatinine Kit, Enzymatic (Crystal Chem, Inc., Downers Grove, IL). All samples were performed in triplicate.

\section{Lipid Peroxides}

$\mathrm{CD} 11 \mathrm{~b}^{+}$isolated cells were placed in cold antioxidant buffer and snap-frozen, stored at $-80^{\circ} \mathrm{C}$ until analysis $(n=4$ to 5 per group), and were homogenized in $500 \mu \mathrm{L}$ of phosphatebuffered saline with $100 \mu \mathrm{mol} / \mathrm{L}$ butylated hydroxytoluene and $1 \mu \mathrm{mol} / \mathrm{L}$ diethylene tetraamino pentaacetic acid $(\mathrm{pH} 7)$, followed by the addition of an internal standard cocktail that contained isotopically labeled 9(S)-hydroxyoctadecadienoic acid (HODE)-d4, 13-(S)HODE-d4, 5-(S) hydroxyeicosatetraenoic acid (HETE)-d8, 12-(S)HETE-d8, 15-(S)HETE-d8, 20-(S)HETE-d6, arachidonic acid-d8, and linoleic acid-d4 (Cayman Chemicals, Ann Arbor, MI). For isoprostane measurements, prostaglandin $\mathrm{F} 2 \alpha-\mathrm{d} 4$ was also added as an internal standard. The samples were incubated with an excess amount of sodium borohydride for 5 minutes, subjected to base hydrolysis with $1 \mathrm{~mol} / \mathrm{L}$ potassium hydroxide in methanol under nitrogen for 1 hour at $40^{\circ} \mathrm{C}$. The reaction was terminated by the addition of $2 \mathrm{~mL}$ of $10 \%$ acetic acid, lipids were extracted with chloroform/ethyl acetate $(4: 1, \mathrm{v} / \mathrm{v})$, and the organic layers were pooled and dried. Samples were subjected to reverse-phase liquid chromatography for hydroxyoctadecadienoic acid 

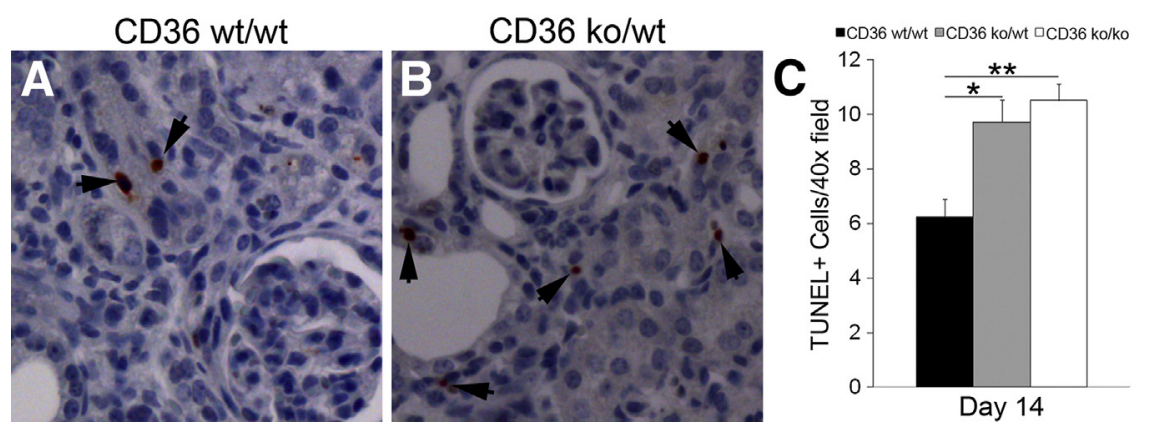

Figure 4 Macrophage CD36 clears apoptotic cells during chronic kidney injury. Apoptotic cells were identified by TUNEL staining in day 14 UUO kidneys. A and B: Representative images with arrows that denote TUNEL ${ }^{+}$apoptotic cells. C: Graph summarizes analysis by $U$ test. Data are expressed as means \pm SEM. $n=5$ to 6 per group. ${ }^{*} P<0.05$, $* * P<0.01$. Original magnification, $\times 400$. ko, knockout; TUNEL, terminal deoxynucleotidyl transferase-mediated dUTP nick-end labelling; UU0, unilateral ureteral obstruction; wt, wild-type.
(HODE), hydroxyeicosatetraenoic acid (HETE), arachidonic acid, linoleic acid, and prostaglandin F2 $\alpha$ analysis by using an Agilent 1200 LC system (Agilent Technologies, Santa Clara, CA). ${ }^{25}$ Mass spectrometric experiments were performed with an Agilent Technologies 6410 Triple Quadrupole system equipped with an electrospray source. Quantification of oxidized fatty acids and their precursors were performed by comparing peak areas of the analyte of interest and their corresponding isotopically labeled internal standard. The levels of the oxidized fatty acid (HODEs and HETEs) were normalized to precursor fatty acids (linoleic and arachidonic acids), respectively. 8-Iso-prostaglandinF2 $\alpha$ was measured by monitoring transition of the $m / z 353$ to 193 and $\mathrm{m} / \mathrm{z} 357$ to 193 to quantify native 8-iso-prostaglandin-F2 $\alpha$ and its isotopically labeled internal standard 8iso-prostaglandin-F2 $\alpha$-d4 . Levels were normalized to arachadonic acid, the precursor fatty acid.

\section{Statistical Analysis}

All data are presented as the means \pm SEM. All statistical analyses were performed with STATA version 12 (StataCorp LP, College Station, TX). A nested analysis of variance was used for all semiquantitative computer-assisted image analysis data. For the latter, the arithmetic mean of six randomly selected images of slides for each animal was used to calculate the reported mean of the group and the SEM. All other results were analyzed by unpaired Student's $t$-test. Nonparametric data (TUNEL and tubular injury data) were analyzed with the $U$ test. $P<0.05$ was considered statistically significant.

\section{Results}

\section{CD36 Identifies an M2 Phagocytic Macrophage}

We investigated CD36 expression by macrophages in response to $\mathrm{M} 1$ and $\mathrm{M} 2$ activation by using $\mathrm{CD} 36^{+/+}$BMDMs. CSF1 stimulation of bone marrow cells resulted in a high level of CD36 expression in BMDMs at baseline (Figure 1A). M2 activation of BMDMs led to an increase in CD36 expression in which almost the entire subset was $\mathrm{F} 4 / 80^{+} \mathrm{CD} 11 \mathrm{c}^{\mathrm{hi}}$ (Supplemental Figure S1), whereas M1 activation led to a decrease in CD36 expression (Figure 1, B and C). During kidney injury, most interstitial macrophages are derived from infiltrating circulating monocytes. ${ }^{26}$ Therefore, we used peritoneal TEMs as a model of monocyte-derived tissue macrophages. To investigate the role of CD36 in macrophage activation, we analyzed the cytokine response of TEMs from $\mathrm{CD}^{+/+}$and $\mathrm{CD}^{-1-}$ mice after M1 and M2 activation. We found no significant difference in the expression pattern of major proinflammatory and profibrotic cytokines between wild-type and $\mathrm{CD}^{-1-}$ TEMs after activation (Supplemental Table S1).

To characterize the subset of CD36 macrophages during chronic kidney injury, we performed fluorescent-activated cell sorting analysis on different time points after UUO. In normal kidneys, resident CD36 macrophages are present in the interstitial spaces with long, delicate, cytoplasmic extensions around tubular cells (Figure 1, D-F). With the onset of obstruction, CD36 macrophages comprised a significant proportion of the macrophage $\left(\mathrm{F} 4 / 80^{+}\right)$population (Figure $1, \mathrm{G}-\mathrm{I}$ ) by fluorescent-activated cell sorting analysis, $48 \%$ to $72 \%$ of the phagocytic subpopulation $\left(\mathrm{CD} 45^{+} \mathrm{F} 4 / 80^{+}\right)$expressed CD36 between days 5 and 14 after UUO (Figure 1J). We further analyzed the renal interstitial leukocyte compartment $\left(\mathrm{CD} 45^{+}\right)$ to determine monocyte-derived $\left(\mathrm{CD}_{11} \mathrm{~b}^{+}\right)$from resident $\left(\mathrm{CD} 11 \mathrm{c}^{+}\right)$macrophage populations during UUO. We found that CD36 macrophages infiltrate from the circulation and increased in number by up to 38 -fold, peaking at day 7 when the

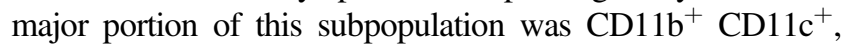
$54 \%$ to $74 \%$ between days 5 and 14 after UUO (Figure $1 \mathrm{~K}$ and Supplemental Figure S2).

CD36 is a well-established macrophage receptor that binds and phagocytoses apoptotic cells and other oxidized lipids. ${ }^{15,27}$ To investigate the effect of CD36-mediated phagocytosis of apoptotic cells, we examined the expression pattern of known proinflammatory and profibrotic cytokines after TEM co-culture with apoptotic tubular cells. Apoptotic renal tubular cells (Annexin $\mathrm{V}^{+}$) were generated by irradiation (Figure 2, A and B) and co-cultured with either $\mathrm{CD} 36^{+/+}$TEMs or $\mathrm{CD}^{-1-} 6^{-1-}$ TEMs (Figure 2, C and D). Apoptotic tubular epithelial cells were more likely to be engulfed by CD36 ${ }^{+/+}$TEMs (Figure 2C) than in the absence of the CD36 receptor (Figure 2D) and consistent with previous reports. ${ }^{15,27} \mathrm{We}$ observed that $\mathrm{CD} 36^{+}$macrophage phagocytosis of apoptotic cells resulted in a significant upregulation of proinflammatory (TNF $\alpha, 84$-fold; TNF $\alpha$ receptor 1, 7-fold) (Figure 2, E and F) and profibrotic [transforming growth factor (TGF $\beta$ )- $\beta 1,10$-fold; TGF $\beta$ - $\beta$ receptor, 20 -fold] 

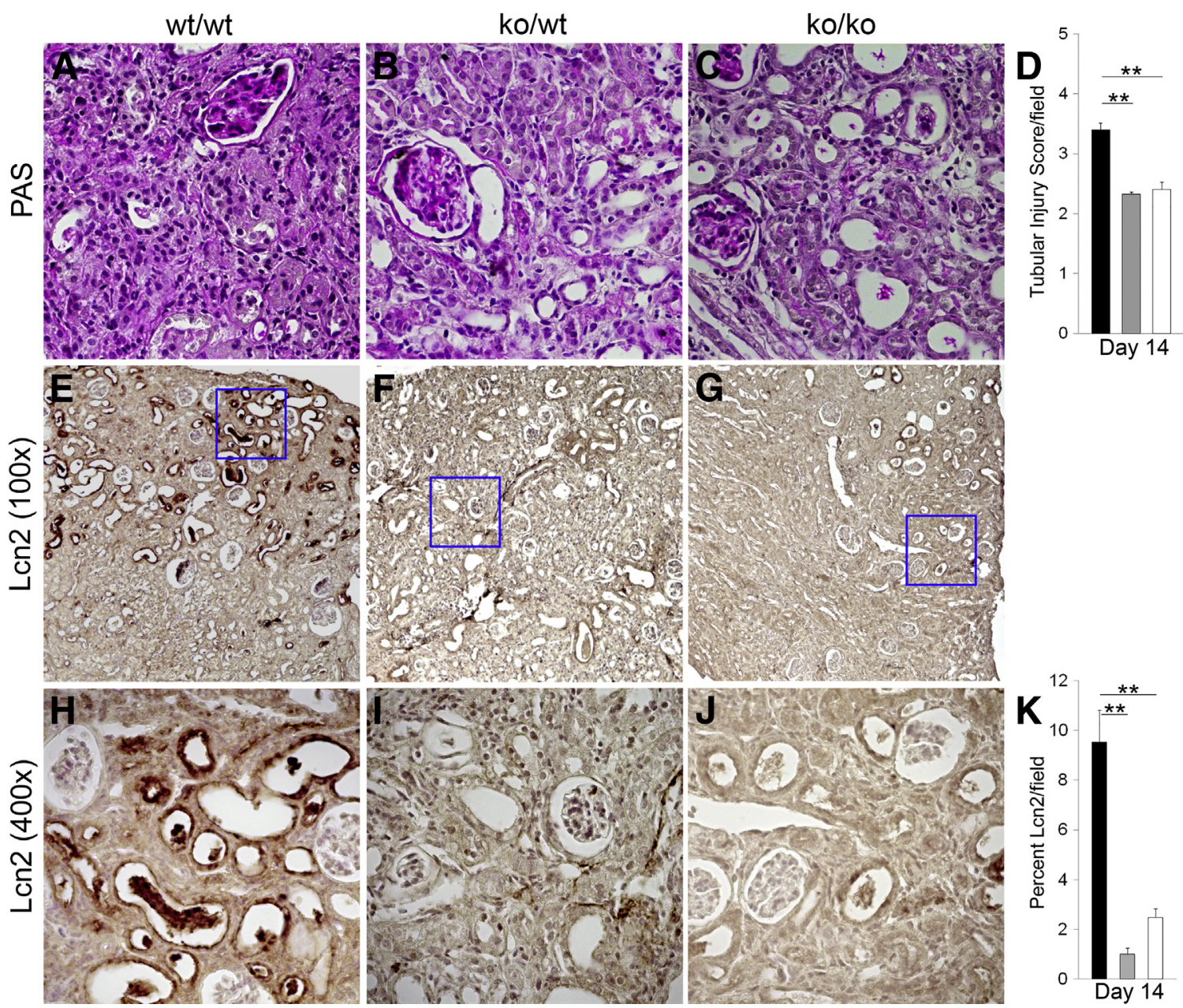

Figure 5 Macrophage CD36 promotes tubular injury. PAS-stained sections were analyzed for tubular injury. A-C: Representative images from day 14 UU0 kidneys of CD36 chimeric mice. D: Graph summarizes the results of PAS tubular injury scores analyzed by $U$ test. Lcn2 is a marker of renal tubular injury. Representative images of Lcn2 from low power $(\mathbf{E}-\mathbf{G})$ and high power $(\mathbf{H}-\mathbf{J})$ in chimeric mice. Boxed areas indicate area of high power image. $\mathbf{K}$ : Graph summarizes semiquantitative image analysis of Lcn2 staining by nested analysis of variance. Solid bar representsCD36 $6^{\mathrm{wt} / \mathrm{wt}}$; gray bar, $\mathrm{CD} 36^{\mathrm{ko} / \mathrm{wt}}$; open bar, $\mathrm{CD} 36^{\mathrm{ko} / \mathrm{ko}}$. Data are expressed as means \pm SEM. $n=5$ to 6 per group $(\mathbf{D}) ; n=6$ to 7 per group $(\mathbf{K})$. ${ }^{* *} P<0.01$. Original magnification: $\times 400(\mathbf{A}-\mathbf{C}) ; \times 100$ (E-G). ko, knockout; Lcn2, Lipocalin 2; PAS, periodic acid-Schiff; UU0, unilateral ureteral obstruction; wt, wild-type.

(Figure 2, G and H) gene expression. At baseline, a nonsignificant increase was found in in TNF $\alpha$ receptor 1 and TGF- $\beta 1$ receptor mRNA expression levels between $\mathrm{CD} 36^{+/+}$and CD36 ${ }^{-1-}$ macrophages (both $P=0.051$ ). However, in the absence of the CD36-mediated phagocytosis all four genes were significantly down-regulated with the largest decreases seen in TNF $\alpha(81 \%)$ and TGF- $\beta 1$ receptor $(99.6 \%)$ mRNA expression levels (Figure 2, E-H). Taken together, these data suggested the following about CD36 kidney macrophages: i) M2 activation promoted CD36 expression, ii) during chronic injury interstitial CD $36^{+}$macrophages expressed phagocytic markers, and iii) CD36-mediated phagocytosis of apoptotic cells resulted in substantial up-regulation of proinflammatory and profibrotic cytokines.

\section{CD36 Macrophages Promote Fibrosis after UU0}

To differentiate the in vivo macrophage CD36-specific effects, we generated CD36 chimeric mice by bone marrow transplantation (donor/recipient: $\mathrm{CD} 36^{\mathrm{ko} / \mathrm{wt}}$ with the appropriate chimeric controls of $\mathrm{CD} 36^{\mathrm{wt} / \mathrm{wt}}$ and $\mathrm{CD} 36^{\mathrm{ko} / \mathrm{ko}}$ ) and performed UUO surgery. A $28 \%$ decrease in fibrosis severity was observed by total collagen assay in $\mathrm{CD} 36^{\mathrm{ko} / \mathrm{wt}}$ compared with $\mathrm{CD} 36^{\mathrm{wt} / \mathrm{wt}}$ chimeric controls (Figure 3A). This was confirmed histologically with picrosirius red staining, where we found a nearly $40 \%$ decrease in fibrosis severity in $\mathrm{CD} 36^{\mathrm{ko} / \mathrm{wt}}$ mice (Figure 3, $\mathrm{B}-\mathrm{D})$. In addition, a corresponding decrease was found in steady state mRNA levels of fibronectin $(69 \%)$ and procollagen $1(53 \%)$ in $\mathrm{CD} 36^{\mathrm{ko} / \mathrm{wt}}$ mice at day 14 after UUO compared with $\mathrm{CD} 36^{\mathrm{wt} / \mathrm{wt}}$ chimeric controls (Figure 3E). Although there was a trend toward decreased procollagen 3 expression in $\mathrm{CD} 36^{\mathrm{ko} / \mathrm{wt}}$ mice, this was not statistically significant. Furthermore, the decreased fibrosis severity phenotype in the $\mathrm{CD} 36^{\mathrm{ko} / \mathrm{wt}}$ mice was similar to the $\mathrm{CD} 36^{\mathrm{ko} / \mathrm{ko}}$ chimeric control and suggested that macrophage CD36 was an important factor in mitigating its profibrotic effect. 


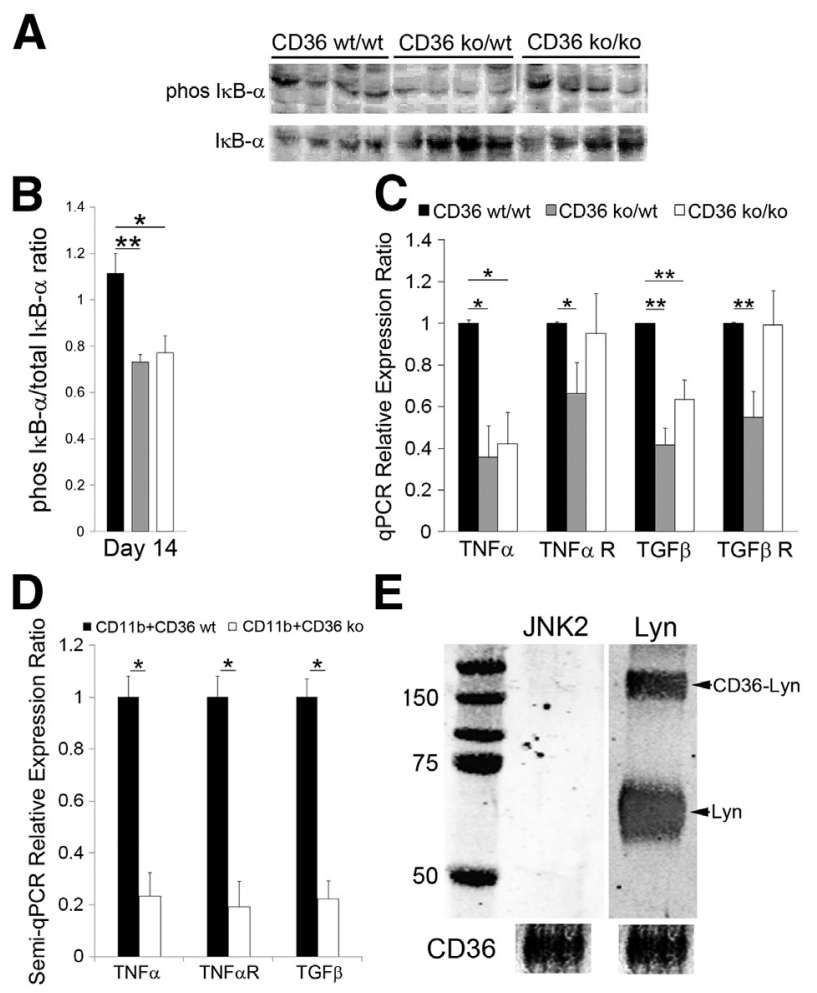

Figure 6 Macrophage CD36 activates fibrogenic signaling pathways. A:

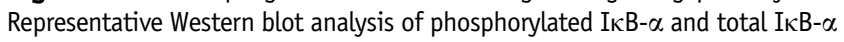
from total kidney homogenate of day 14 UU0 kidneys. B: Graph summarizes results of quantification of band densities of phosphorylated IKB- $\alpha$ and total I $\mathrm{B}-\alpha$ ratios. Proinflammatory and profibrotic mRNA levels in total RNA from whole kidney were measured by semi-qPCR and were normalized to two housekeeping genes, $18 \mathrm{~S}$ and GAPDH. C: The graph summarizes the results on day 14 UU0 kidneys from CD36 chimeric mice. CD11b ${ }^{+}$cells were isolated from day14 UUO kidneys of $\mathrm{CD} 6^{+/+}$and $\mathrm{CD} 36^{-/-}$mice, and total RNA was analyzed by semi-qPCR normalized to $18 S$ and GAPDH. D: Graph summarizes the mRNA expression levels of proinflammatory and profibrotic cytokines. CD36 coimmunoprecipitation was performed on a pooled sample of DSP-treated, $\mathrm{CD}_{11 \mathrm{~b}^{+}}$isolated cells from day 7 UU0 kidneys to determine intracellular signaling binding partners. Co-immunoprecipitation proteins were eluted from CD36 antibody beads, and Western blot analysis was performed. E: Representative Western blot analysis probed for JNK2 and Lyn kinase. Data are expressed as means \pm SEM. $n=5$ to 6 per group. ${ }^{*} P<0.05,{ }^{*} P<0.01$. DSP, dithiobis(succinimidyl propionate); I $\kappa \mathrm{B}-\alpha$, nuclear factor of $\kappa$ light polypeptide gene enhancer in B-cells inhibitor $\alpha$; JNK2, c-Jun N-terminal kinase-2; ko, knockout; semi-qPCR, semiquantitative real-time PCR; TGF, transforming growth factor; TNF, tumor necrosis factor; UU0, unilateral ureteral obstruction; wt, wild-type.

\section{Increased Apoptotic Cells in the Absence of Macrophage CD36}

Because current techniques to definitively identify phagocytosed apoptotic cells in vivo are limited, a defect in apoptotic cell clearance could be inferred from the number of TUNEL ${ }^{+}$cells. Despite a decrease in fibrosis severity, a $56 \%$ increase was observed in TUNEL $^{+}$apoptotic cells in CD36 $6^{\mathrm{k} / \mathrm{wt}}$ compared with CD36 ${ }^{\mathrm{wt} / \mathrm{wt}}$ chimeric controls (Figure 4). On the basis of their location, most of these $\mathrm{TUNEL}^{+}$cells appeared to be tubular cells. To differentiate whether CD36 promoted apoptosis or regulated clearance of apoptotic cells, we examined the expression levels of three effector apoptosis genes that represent both the intrinsic and extrinsic pathways by semiqPCR: Bax, BBC3 (PUMA), and Bcl211 (Bim). ${ }^{28-31}$ Despite an increase in $\mathrm{TUNEL}^{+}$cells, we did not observe any substantial increase in the mRNA levels of these apoptosis effector genes in $\mathrm{CD} 36^{\mathrm{ko} / \mathrm{wt}}$ mice (Supplemental Table S2).

\section{CD36 Macrophages Promote Tubular Injury}

To determine the effect of increased apoptotic tubular cells on tubular health, periodic acid-Schiff-stained sections were analyzed for tubular injury. Despite an increase in apoptotic cells, a significant decrease in tubular injury scores was observed in CD36 $6^{\mathrm{ko} / \mathrm{wt}}$ mice compared with CD36 ${ }^{\mathrm{wt} / \mathrm{wt}}$ chimeric controls after UUO (Figure 5, A-D). Lcn2 is the mouse homolog of neutrophil gelatinase-associated lipocalin, an established marker of distal tubular injury that correlates with kidney dysfunction. ${ }^{32,33} \mathrm{Lcn} 2$ was expressed at low levels in distal tubules in normal kidneys and was substantially up-regulated immediately after kidney injury. Consistent with tubular injury scores, we found a significant reduction in Lcn2 expression levels in both $\mathrm{CD} 36^{\mathrm{ko} / \mathrm{wt}}(89 \%)$ and $\mathrm{CD} 36^{\mathrm{ko} / \mathrm{ko}}(74 \%)$ compared with CD36 ${ }^{\mathrm{wt} / \mathrm{wt}}$ chimeric controls after UUO (Figure 5, E-K). Interestingly, a nonsignificant trend was observed toward less tubular injury in the $\mathrm{CD} 36^{\mathrm{ko} / \mathrm{wt}}$ mice than in the $\mathrm{CD} 36^{\mathrm{ko} / \mathrm{ko}}$ chimeric control. Taken together, these data suggested that, although loss of macrophage CD36 led to increased apoptotic cells, there was less tubular injury after UUO.

\section{CD36 Macrophages Promote Fibrogenic Signaling and Oxidative Stress}

To determine the effect of retained apoptotic cells on the tissue microenvironment we examined established proinflammatory and profibrotic mediators in chimeric mice after UUO. Our previous studies demonstrated that CD36 activated the nuclear translocation of the p50p65 heterodimer. ${ }^{18} \mathrm{We}$ examined phosphorylated I $\kappa \mathrm{B}-\alpha$ levels by Western blot analysis as a measure of NF- $\kappa \mathrm{B}$ activation. We found a $30 \%$ decrease in tissue levels of NF- $\mathrm{KB}$ activation in $\mathrm{CD} 36^{\mathrm{ko} / \mathrm{wt}}$ compared with $\mathrm{CD} 36^{\mathrm{wt} / \mathrm{wt}}$ chimeric controls, levels that were similar to $\mathrm{CD} 36^{\mathrm{ko} / \mathrm{ko}}$ mice (Figure 6, A and B). At day 14 after UUO, the steady state mRNA tissue levels of TNF $\alpha$ and TGF- $\beta 1$ were significantly decreased by $64 \%$ and $58 \%$, respectively, in CD36 $6^{\mathrm{ko} / \mathrm{wt}}$ compared with $\mathrm{CD} 36^{\mathrm{wt} / \mathrm{wt}}$ chimeric controls (Figure 6C). We also found reductions in expression levels of TNF $\alpha$ receptor 1 and TGF- $\beta 1$ receptor (Figure 6C) and a nonsignificant trend toward decreases in mRNA levels of inducible nitric oxide synthase and NADPH oxidase-2 and -4 (Supplemental Table S3). To demonstrate that this effect on cytokine expression is primarily because of CD36 macrophages, we isolated $\mathrm{CD} 11 \mathrm{~b}^{+}$macrophages from UUO kidneys of $\mathrm{CD} 36^{+/+}$and $\mathrm{CD} 36^{-/-}$mice and examined their transcriptome. A nearly $80 \%$ reduction was observed in steady state mRNA levels of TNF $\alpha, \mathrm{TNF} \alpha$ receptor 1 , and TGF- $\beta 1$ in $\mathrm{CD} 36^{-1-}$ compared with $\mathrm{CD} 36^{+/+}$isolated macrophages 

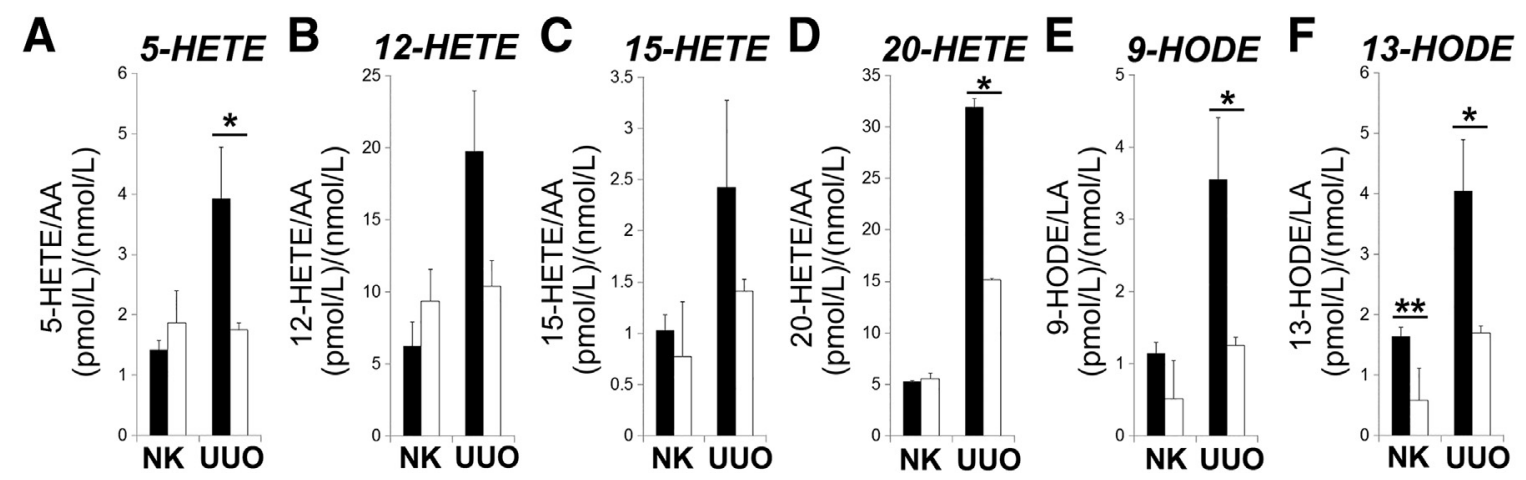

Figure 7 Macrophage bioactive lipids are reduced in the absence of CD36. Interstitial macrophages (CD11 $\mathrm{b}^{+}$) were isolated from contralateral (NK) and UUO day 14 kidneys from ${\mathrm{CD} 36^{+/+}}$and $\mathrm{CD} 36^{-/-}$mice. Samples were analyzed by reverse-phase HPLC and mass spectrometry for 5-, 12-, 15-, 20-HETE (A-D) and 9S-, 13S-HODE (E and F). Concentrations were normalized to their precursor: AA for HETEs and LA for HODEs. Black bar represents CD36 ${ }^{+/+}$; white bar, $\mathrm{CD}^{-/-}$. Data are expressed as means \pm SEM. $n=4$ to 5 per group. ${ }^{*} P<0.05,{ }^{*} P<0.01$. AA, arachidonic acid; HETE, hydroxyeicosatetraenoic acid; HODE, hydroxyoctadecadienoic acid; HPLC, high-performance liquid chromatography; LA, linoleic acid; NK, normal kidney; UU0, unilateral ureteral obstruction.

(Figure 6D). Interestingly, TGF- $\beta 1$ receptor mRNA was expressed at low levels in both $\mathrm{CD}_{11} 1 \mathrm{~b}^{+}$macrophages from $\mathrm{CD}^{+/+}$and $\mathrm{CD} 36^{-/-}$mice $\left(\mathrm{C}_{\mathrm{T}} \geq 40\right)$. CD36 does not directly activate signal transduction pathways and relies on intracellular binding partners. ${ }^{34}$ Therefore, we performed a coimmunoprecipitation for $\mathrm{CD} 36$ on $\mathrm{CD} 11 \mathrm{~b}^{+}$macrophages isolated from UUO kidneys of CD $36^{+/+}$mice and analyzed it by Western blot analysis for Lyn kinase and JNK2, the two primary intracellular proteins associated with CD36 signaling. ${ }^{35-37} \mathrm{We}$ found that CD36 binds to Lyn kinase not JNK2 and initiated signaling pathways in fibrogenic interstitial renal macrophages (Figure 6E).

Because CD36 binds oxidized lipids, we investigated intracellular lipid peroxides (HETE and HODE) in isolated interstitial CD $11 \mathrm{~b}^{+}$macrophages in CD $36^{+/+}$and CD $36^{-/-} \mathrm{UUO}$ and contralateral kidneys. We found a large increase in the generation of intracellular HETEs and HODEs after chronic injury by obstruction in $\mathrm{CD} 36^{+/+}$UUO macrophages compared with contralateral macrophages: 5-HETE (2.8-fold), 12-HETE (3.2-fold), 15-HETE (2.4-fold), 20-HETE (6.1-fold), 9SHODE (3.1-fold), and 13S-HODE (2.5-fold) (Figure 7). However, in the absence of CD36 a significant reduction was found in the intracellular generation of 5-HETE (55\%), 20HETE $(53 \%)$, 9S-HODE (65\%), and 13S-HODE (58\%) in fibrogenic macrophages (Figure 7, A and D-F). Interestingly, a significant reduction was found in baseline (contralateral) $13 \mathrm{~S}$ HODE levels in CD $36^{-/-}$compared with $\mathrm{CD} 36^{+/+}$isolated macrophages (Figure 7F) that could account for the changes seen after UUO because the rate of change is similar.

\section{CD36 Macrophages Promote Nephron Loss after Ischemic Injury}

To validate the profibrotic role of CD36 macrophages, we used a second model of kidney injury, IR. Macrophage CD36 chimeric mice were generated by bone marrow transplantation with appropriate chimeric controls and underwent unilateral IR, followed by contralateral nephrectomy at day 14 to determine kidney function at days 17 and 28 after IR ( 3 and 14 days after nephrectomy). Because the $\mathrm{CD} 36^{\mathrm{ko} / \mathrm{wt}}$ phenotype was similar to the $\mathrm{CD} 36^{\mathrm{ko} / \mathrm{ko}}$ chimeric control in our UUO model, we only generated the $\mathrm{CD} 36^{\mathrm{wt} / \mathrm{wt}}$ chimera for the IR model. We found a significant reduction in blood urea nitrogen $(58 \%)$ and creatinine $(88 \%)$ concentrations at day 28 in $\mathrm{CD} 36^{\mathrm{ko} / \mathrm{wt}}$ compared with $\mathrm{CD} 36^{\mathrm{wt} / \mathrm{wt}}$ chimeric controls (Figure 8, A and B). This correlated with a reduction in fibrosis severity with a $46 \%$ decrease in total collagen in CD36 ${ }^{\mathrm{ko} / \mathrm{wt}}$ compared with CD36 ${ }^{\mathrm{wt} / \mathrm{wt}}$ mice at day 28 (Figure $8 \mathrm{C}$ ). This was confirmed histologically by a $55 \%$ reduction in picrosirius red staining in $\mathrm{CD} 36^{\mathrm{ko} / \mathrm{wt}}$ mice at day 28 (Figure 8, D-F). Unexpectedly, the absence of macrophage CD36 led to a significant improvement in kidney function between days 17 and 28 after IR injury (CD $36^{\mathrm{ko} / \mathrm{wt}}$ versus CD $36^{\mathrm{wt} / \mathrm{wt}}$ : creatinine, $-35 \% \pm 10 \%$ versus $326 \pm 94 \% ; P=0.008$ ) (Figure $8 \mathrm{G}$ ).

A nonsignificant trend was found in more apoptotic cells in $\mathrm{CD} 36^{\mathrm{ko} / \mathrm{wt}}$ mice compared with $\mathrm{CD} 36^{\mathrm{wt} / \mathrm{wt}}$ mice at day 28 after IR $\left(\mathrm{CD} 36^{\mathrm{ko} / \mathrm{wt}}\right.$ versus $\mathrm{CD} 36^{\mathrm{wt} / \mathrm{wt}} ; n=8$ per group; $6.8 \pm 0.7$ versus $5.0 \pm 1.6 \mathrm{TUNEL}^{+}$cells/field; $P=0.4$ ). No difference in mRNA levels of apoptosis effector genes were found (data not shown). However, tubular injury scores were significantly reduced in $\mathrm{CD} 36^{\mathrm{ko} / \mathrm{wt}}$ mice compared with chimeric controls (Figure 9, A-C); this correlated with a significant reduction in Lcn 2 expression by $>90 \%$ (Figure 9, D-H). Fibrogenic gene expression was also down-regulated in $\mathrm{CD} 36^{\mathrm{ko} / \mathrm{wt}}$ mice compared with chimeric controls after IR: TNF $\alpha$ and TNF $\alpha$ receptor 1 were significantly decreased by $>90 \%$; and a nonsignificant decrease in TGF- $\beta 1$ expression by $>80 \%$ $(P=0.2)$ (Figure 9I). No substantial difference was observed in TGF- $\beta 1$ receptor expression (data not shown). These studies suggested that macrophage CD36 not only promoted fibrogenic pathways and tubular injury but inhibited repair.

\section{Discussion}

\section{CD36 Identifies a Profibrotic Macrophage}

Identification and characterization of the profibrotic M2 macrophage subset is vital for developing therapeutic targeting 

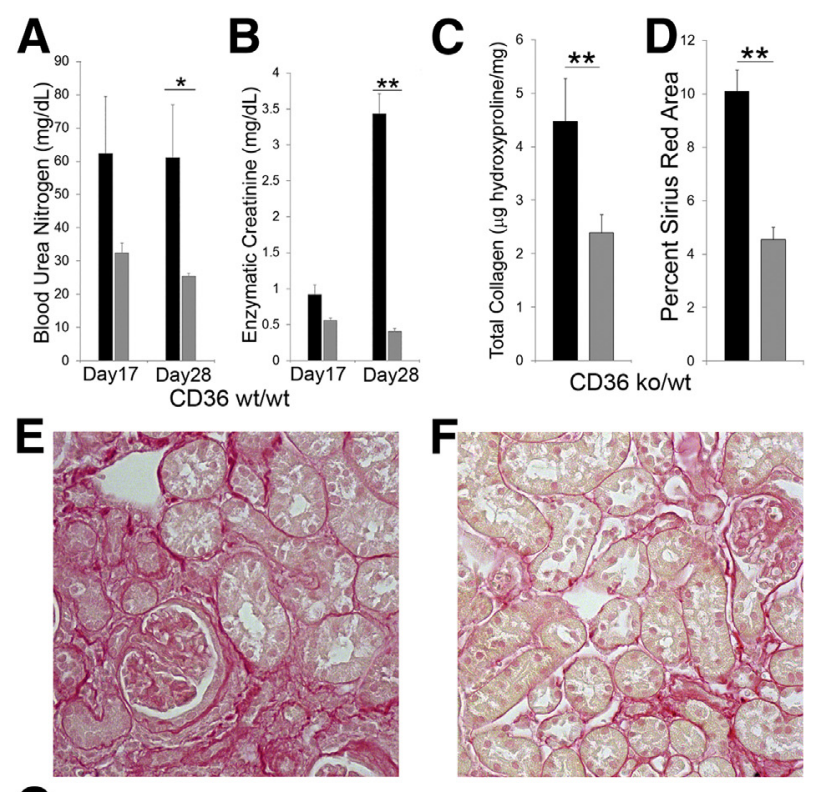

G
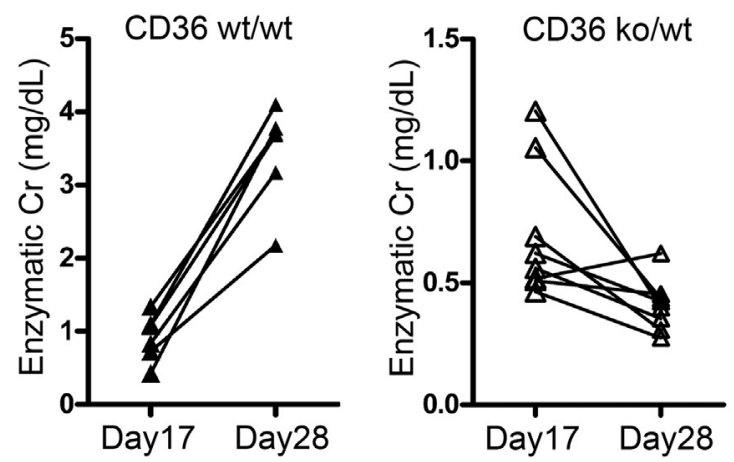

Figure 8 Absence of $\mathrm{CD} 36$ macrophages improves kidney function after ischemic injury. Unilateral IR was performed, and the contralateral kidney was surgically removed at day 14 after IR. Phlebotomy was performed at day 17 and 28 (sacrifice). Graphs summarize the results of BUN (A) and enzymatic creatinine (B) concentrations from CD36 chimeric mice. Total kidney collagen content was measured by hydroxyproline assay and summarized in graph C. D: Graph summarizes image analysis of picrosirius red ${ }^{+}$interstitial collagen quantification by nested analysis of variance, with representative images ( $\mathbf{E}$ and $\mathbf{F})$. The fold change $(\delta)$ in enzymatic creatinine from day 17 to day 28 was calculated and analyzed by Student's $t$-test. G: Graphs demonstrate the change in $\mathrm{Cr}$ in CD36 chimeric mice (mean fold change: $\mathrm{CD} 36^{\mathrm{wt} / \mathrm{wt}}=\delta 3.3 \pm 0.9 \mathrm{mg} / \mathrm{dL}$ versus $\left.\mathrm{CD} 36^{\mathrm{ko} / \mathrm{wt}}=\delta-0.4 \pm 0.1 \mathrm{mg} / \mathrm{dL}\right)$. Black bar representsCD36 ${ }^{\mathrm{wt} / \mathrm{wt}}$; gray bar, $\mathrm{CD} 36^{\mathrm{ko} / \mathrm{wt}}$. Data are expressed as means \pm SEM. $n=6$ to 8 per group. ${ }^{*} P<0.05,{ }^{* *} P<0.01$. Original magnification, $\times 400$. BUN, blood urea nitrogen; $\mathrm{Cr}$, creatinine; IR, ischemia reperfusion; KO, knockout; wt, wild-type.

strategies to limit the progression of solid-organ fibrosis. The present study is the first to define the functional role of the CD36 macrophage in chronic kidney injury as a profibrotic M2 phenotype. CSF1 is a critical cytokine in monocyte-tomacrophage differentiation and in the development of tissue macrophages. ${ }^{38-40}$ Our study demonstrated that CSF1 stimulation resulted in a strong up-regulation of CD36 surface expression and suggested that most of these monocyte-derived kidney tissue macrophages were CD36-bearing cells. This was confirmed by our finding that CD36 identified a subpopulation of phagocytic macrophages that increased in number and infiltrated the kidney during chronic injury. Several studies in solid-organ injury demonstrated that ablation of monocytederived macrophages resulted in a substantial attenuation in fibrosis, ${ }^{3,4,26,41-44}$ and, on the basis of our study, this could perhaps be attributed to elimination of the CD36 subpopulation.

\section{CD36 Phenotype Responds to the Microenvironment}

Results of our in vitro studies further supported that M2 activation with IL-4 up-regulates CD36 expression, whereas M1 activation with lipopolysaccharide and interferon- $\gamma$ resulted in down-regulation of the receptor. Studies demonstrate that IL-4-stimulated macrophages lead to tissue repair, promoted tubular cell proliferation, and attenuated renal fibrosis. ${ }^{9,45}$ Although IL-4 up-regulated CD36 expression, our data provided strong evidence that the phenotype of macrophage CD36 positivity/expression promotes the progression of fibrosis and subsequent nephron loss; the presence of CD36-deficient macrophages resulted in a $30 \%$ to $40 \%$ reduction in fibrosis severity with a corresponding improvement in kidney function. In addition, several studies have demonstrated that macrophage CD36 plays a critical role in activating and perpetuating a proinflammatory cascade during sepsis. ${ }^{46-48}$ Taken together, these findings illustrate the discrepancy between the M1/M2 paradigm and the impact of the tissue microenvironment on macrophage phenotype which is in agreement with previous work that ex vivo-primed macrophages can switch phenotype within the kidney likely because of cues in the microenvironment. ${ }^{9}$ We further provide strong evidence that macrophage CD36 directed the generation of a fibrogenic milieu within the injured kidney microenvironment. A 50\% to $60 \%$ reduction was observed in kidney levels of important proinflammatory and profibrotic cytokines TNF $\alpha$ and TGF- $\beta 1$, and a $30 \%$ reduction in NF- $\kappa \mathrm{B}$ activation in macrophage CD36-deficient mice. Furthermore, our in vitro data suggest that these CD36-mediated signaling patterns are not produced by M1 or M2 activation but rather by oxidized lipid ligands such as apoptotic cells.

\section{CD36-Dependent Phagocytosis Alters Fibrogenesis}

A critical step in understanding the mechanisms involved in the profibrotic effects of macrophage CD36 is determining the relevant ligands during chronic injury. CD36 functions as a pattern-recognition, scavenger receptor and binds oxidized phospholipids that can be found on the surface of apoptotic cells and damage-associated molecular pattern molecules. ${ }^{15}$ Our results demonstrated that there was a substantial increase by approximately $60 \%$ in the number of apoptotic cells in macrophage CD36-deficient mice after UUO and a similar trend after IR injury; the diminished difference in apoptotic cells may be related to the acute/subacute nature of IR injury compared with the ongoing cellular damage by obstruction. Despite higher numbers of apoptotic cells in CD36-deficient chimeric mice, renal tubular injury, apoptotic gene effector 

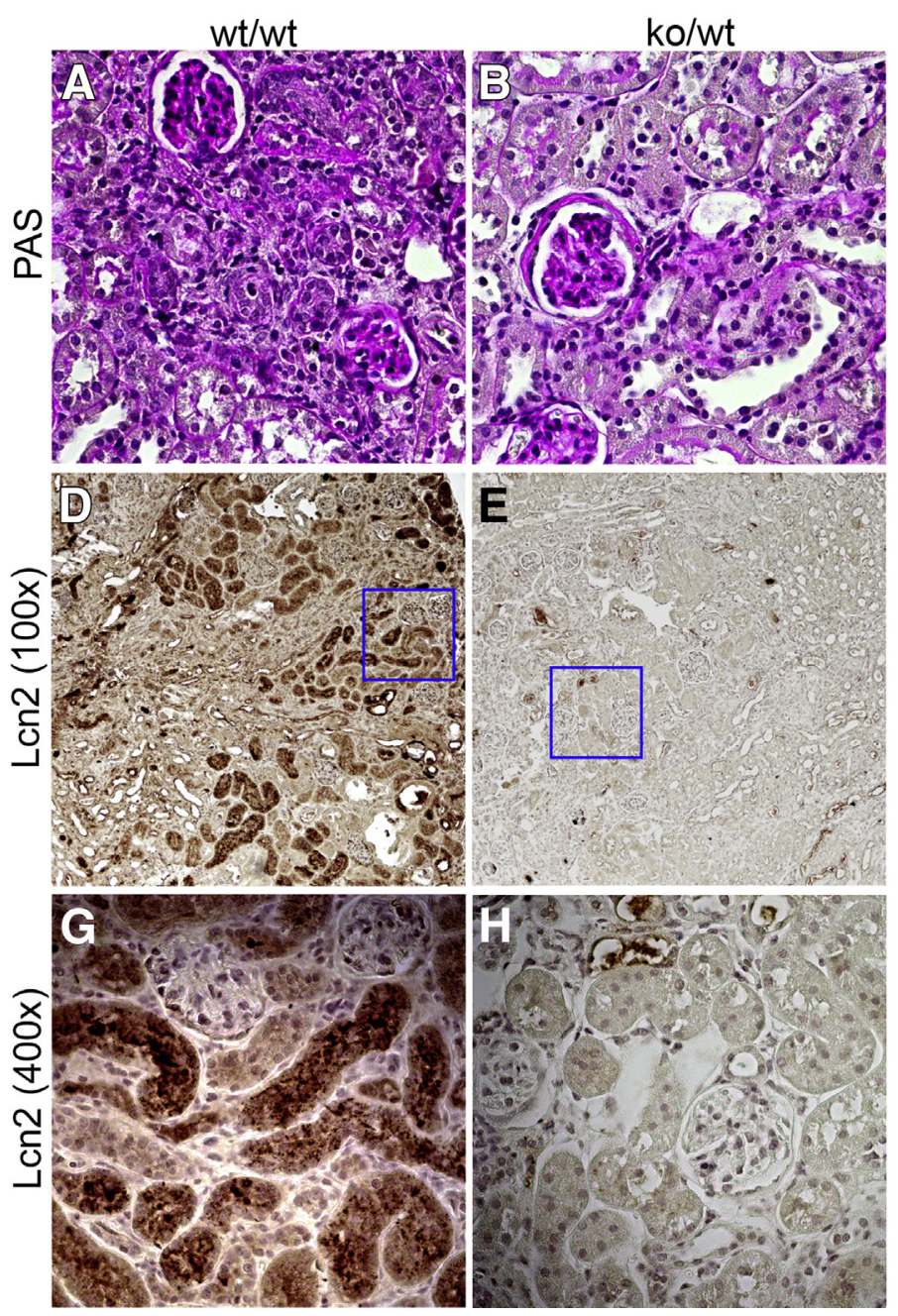
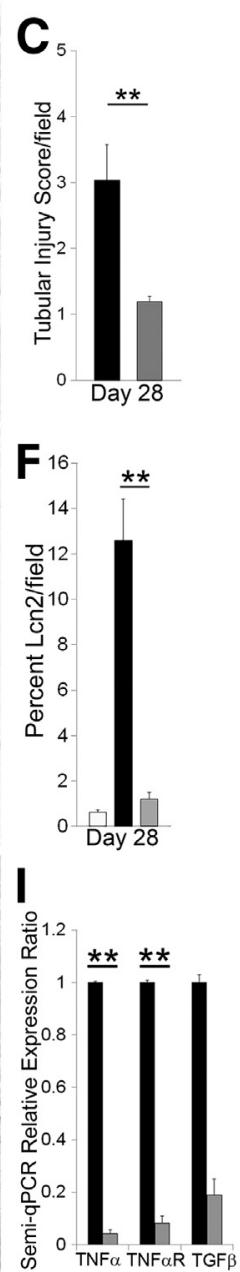

Figure 9 Absence of CD36 macrophages reduces tubular injury. PAS-stained sections were analyzed for tubular injury at day 28 after IR. A and B: Representative images of IR kidneys of CD36 chimeric mice. C: Graph summarizes the results of PAS tubular injury scores analyzed by $U$ test. D and E: Representative images of Lcn2 from low power. F: Graph summarizes semiquantitative image analysis of Lcn2 staining by nested analysis of variance and high power ( $\mathbf{G}$ and $\mathbf{H}$ ) in chimeric mice. Boxed areas in $\mathbf{D}$ and $\mathbf{E}$ indicate area of high-power image. Proinflammatory and profibrotic mRNA levels in total RNA from whole kidney were measured by semiquantitative real-time PCR and normalized to two housekeeping genes, 185 and GAPDH. I: The graph summarizes the results on day 28 IR kidneys from CD36 chimeric mice. Black bar representsCD36 ${ }^{\mathrm{wt} / \mathrm{wt}}$; gray bar, $\mathrm{CD} 36^{\mathrm{ko} / \mathrm{wt}}$; white bar, sham; Data are expressed as means \pm SEM. $n=5$ to 6 per group (C); $n=7$ to 8 per group (F); $n=6$ per group (I). ${ }^{* \star} P<0.01$. Original magnification: $\times 400$ (A and B). IR, ischemia reperfusion; ko, knockout; Lcn2, Lipocalin 2; PAS, periodic acid-Schiff; semi-qPCR, semiquantitative real-time PCR; wt, wild-type. expression, and kidney function were all improved. These findings in combination with known ligands for CD36 suggested that CD36-mediated removal of apoptotic cells and/or damage-associated molecular pattern molecules was an important step in fibrogenesis. Results of our IR model studies further suggest that CD36-mediated removal of apoptotic cells during acute kidney injury may be an important link in the pathway toward chronic kidney disease, because clinical studies have identified acute kidney injury as a major factor in chronic kidney disease progression. ${ }^{49}$ A recent study by Parks et $\mathrm{al}^{50}$ showed that during acute lung injury CD36 was required for the timely removal of apoptotic cells, and pulmonary fibrosis was reduced in the absence of CD36. Alternatively, CD36 macrophages could have provided an important mitogenic stimulus to fibrogenic cells such as myofibroblasts, whereby loss of this CD36 subpopulation led to subsequent apoptosis. A recent study by Xiong et $\mathrm{al}^{51}$ demonstrated that phosphatidylserine exposed on apoptotic cells stimulated the production of TGF- $\beta$ and that this was mediated through the macrophage CD36-Lyn kinase signaling complex. TGF- $\beta 1$ is not only an important mediator of myofibroblast transformation but could serve as a mitogenic stimulus as well. However, our data suggested that most apoptotic cells were tubular cells. Furthermore, a recent study by Huen et $\mathrm{al}^{52}$ suggested that macrophage-derived TGF- $\beta 1$ was not essential for the development of renal fibrosis and suggested that the profibrotic effect of macrophage CD36 may be related to additional fibrogenic factors.

\section{CD36-Dependent Bioactive Lipids in Fibrosis}

Recent studies suggest that phospholipid-derived bioactive lipid mediators may play important roles in priming proinflammatory and anti-inflammatory pathways in macrophage activation. ${ }^{53,54}$ We found that with chronic kidney injury there is a 2- to 6-fold increase in intracellular levels of HETEs and HODEs in kidney macrophages. In the absence of the CD36 receptor, there was a $>50 \%$ decrease in 5-HETE and 20-HETE levels in fibrogenic macrophages. 5-HETE is a bioactive lipid derived from the 5-lipoxygenase (5-LOX) pathway of arachidonic acid metabolism and augments macrophage phagocytosis. ${ }^{55} \mathrm{~A}$ recent study further suggests that 5-Lox products promote macrophage infiltration and promote renal tubular injury. ${ }^{56}$ 
20-HETE is another bioactive lipid derived from cytochrome p450 $\omega$-hydroxylases CYP4A and CYP4F conversion of arachidonic acid. Studies suggest that 20-HETE can cause renal vasoconstriction and can drive kidney injury and podocyte apoptosis in diabetic nephropathy. ${ }^{57,58}$ It is unclear whether macrophage bioactive lipid mediators such as CD36-derived HETEs play a direct or an indirect role in tubulointerstitial injury and progression of fibrosis and is currently under investigation.

\section{Limitations}

Our study did not address the role of CD36 in tubular cells during fibrosis progression. Several studies have demonstrated that in proteinuric disease models, tubular CD36 activates fibrogenic signaling pathways. ${ }^{59-61}$ However, it is not clear if the role of tubular CD36 is ligand and therefore context specific: For example, does the CD36-dependent tubular response to oxidized lipid ligands differ from those of oxidized proteins? Another apoptotic cell receptor kidney injury molecule-1 is up-regulated in proximal tubular cells during kidney injury, phagocytoses apoptotic cells, and promotes fibrosis progression. ${ }^{62,63}$ Whether tubular CD36 plays a redundant or distinct role from kidney injury molecule-1 in fibrosis progression after kidney injury is unclear and is currently under investigation.

\section{Conclusions}

The present study supports the role of CD36 as an important phenotypic marker of the profibrotic M2 macrophage and a key phagocytic receptor for the clearance of apoptotic cells during kidney injury. It further suggests that CD36-dependent removal of apoptotic cells could represent a critical event in the microenvironment that modifies macrophage behavior, generates several bioactive lipid mediators, and activates key pathways in the progression of chronic kidney disease after acute kidney injury. However, our study does not exclude the participation of other apoptotic cell receptors in fibrosis progression. There is a great deal of redundancy in the recognition and clearance of apoptotic cells, and the absence of particular receptors results in the development of autoimmunity whereas others do not. ${ }^{63-68}$ Classic understanding of signaling pathways after phagocytosis of apoptotic cells are based on in vitro studies, but whether this paradigm translates into the context of tissue injury and remodeling requires further investigation.

\section{Acknowledgments}

We thank Drs. Allison Eddy (University of British Columbia, Vancouver, Canada) and Jesus Lopez Guisa (Seattle Children's Research Institute, Seattle, WA) for guidance and useful discussions.

\section{Supplemental Data}

Supplemental material for this article can be found at http://dx.doi.org/10.1016/j.ajpath.2015.04.016.

\section{References}

1. Wahl SM, McCartney-Francis N, Allen JB, Dougherty EB, Dougherty SF: Macrophage production of TGF-beta and regulation by TGF-beta. Ann N Y Acad Sci 1990, 593:188-196

2. Bonner JC, Osornio-Vargas AR, Badgett A, Brody AR: Differential proliferation of rat lung fibroblasts induced by the platelet-derived growth factor- $\mathrm{AA},-\mathrm{AB}$, and $-\mathrm{BB}$ isoforms secreted by rat alveolar macrophages. Am J Respir Cell Mol Biol 1991, 5:539-547

3. Duffield JS, Forbes SJ, Constandinou CM, Clay S, Partolina M, Vuthoori S, Wu S, Lang R, Iredale JP: Selective depletion of macrophages reveals distinct, opposing roles during liver injury and repair. J Clin Invest 2005, 115:56-65

4. Duffield JS, Tipping PG, Kipari T, Cailhier JF, Clay S, Lang R, Bonventre JV, Hughes J: Conditional ablation of macrophages halts progression of crescentic glomerulonephritis. Am J Pathol 2005, 167: $1207-1219$

5. Martinez FO, Gordon S, Locati M, Mantovani A: Transcriptional profiling of the human monocyte-to-macrophage differentiation and polarization: new molecules and patterns of gene expression. J Immunol 2006, 177:7303-7311

6. Anders HJ, Ryu M: Renal microenvironments and macrophage phenotypes determine progression or resolution of renal inflammation and fibrosis. Kidney Int 2011, 80:915-925

7. Ricardo SD, van Goor H, Eddy AA: Macrophage diversity in renal injury and repair. J Clin Invest 2008, 118:3522-3530

8. Duffield JS: Macrophages and immunologic inflammation of the kidney. Semin Nephrol 2010, 30:234-254

9. Lee S, Huen S, Nishio H, Nishio S, Lee HK, Choi BS, Ruhrberg C, Cantley LG: Distinct macrophage phenotypes contribute to kidney injury and repair. J Am Soc Nephrol 2011, 22:317-326

10. Nelson PJ, Rees AJ, Griffin MD, Hughes J, Kurts C, Duffield J: The renal mononuclear phagocytic system. J Am Soc Nephrol 2012, 23: 194-203

11. Porcheray F, Viaud S, Rimaniol AC, Leone C, Samah B, DereuddreBosquet N, Dormont D, Gras G: Macrophage activation switching: an asset for the resolution of inflammation. Clin Exp Immunol 2005, 142:481-489

12. Banerjee S, Xie N, Cui H, Tan Z, Yang S, Icyuz M, Abraham E, Liu G: MicroRNA let-7c regulates macrophage polarization. J Immunol 2013, 190:6542-6549

13. Wang L, Scabilloni JF, Antonini JM, Rojanasakul Y, Castranova V, Mercer RR: Induction of secondary apoptosis, inflammation, and lung fibrosis after intratracheal instillation of apoptotic cells in rats. Am J Physiol Lung Cell Mol Physiol 2006, 290:L695-L702

14. Miller YI, Choi SH, Wiesner P, Fang L, Harkewicz R, Hartvigsen K, Boullier A, Gonen A, Diehl CJ, Que X, Montano E, Shaw PX, Tsimikas S, Binder CJ, Witztum JL: Oxidation-specific epitopes are danger-associated molecular patterns recognized by pattern recognition receptors of innate immunity. Circ Res 2011, 108:235-248

15. Greenberg ME, Sun M, Zhang R, Febbraio M, Silverstein R, Hazen SL: Oxidized phosphatidylserine-CD36 interactions play an essential role in macrophage-dependent phagocytosis of apoptotic cells. J Exp Med 2006, 203:2613-2625

16. Moodley Y, Rigby P, Bundell C, Bunt S, Hayashi H, Misso N, McAnulty R, Laurent G, Scaffidi A, Thompson P, Knight D: Macrophage recognition and phagocytosis of apoptotic fibroblasts is critically dependent on fibroblast-derived thrombospondin 1 and CD36. Am J Pathol 2003, 162:771-779 
17. Savill J, Hogg N, Ren Y, Haslett C: Thrombospondin cooperates with CD36 and the vitronectin receptor in macrophage recognition of neutrophils undergoing apoptosis. J Clin Invest 1992, 90:1513-1522

18. Okamura DM, Pennathur S, Pasichnyk K, Lopez-Guisa JM, Collins S, Febbraio M, Heinecke J, Eddy AA: CD36 regulates oxidative stress and inflammation in hypercholesterolemic CKD. J Am Soc Nephrol 2009, 20:495-505

19. Okamura DM, Lopez-Guisa JM, Koelsch K, Collins S, Eddy AA: Atherogenic scavenger receptor modulation in the tubulointerstitium in response to chronic renal injury. Am J Physiol Renal Physiol 2007, 293:F575-F585

20. Committee for the Update of the Guide for the Care and Use of Laboratory Animals; National Research Council: Guide for the Care and Use of Laboratory Aniamals: Eighth Edition. Washington, DC, National Academies Press, 2011

21. Matsuo S, Lopez-Guisa JM, Cai X, Okamura DM, Alpers CE, Bumgarner RE, Peters MA, Zhang G, Eddy AA: Multifunctionality of PAI-1 in fibrogenesis: evidence from obstructive nephropathy in PAI-1-overexpressing mice. Kidney Int 2005, 67: $2221-2238$

22. Yamaguchi I, Lopez-Guisa JM, Cai X, Collins SJ, Okamura DM, Eddy AA: Endogenous urokinase lacks antifibrotic activity during progressive renal injury. Am J Physiol Renal Physiol 2007, 293: F12-F19

23. Okamura DM, Pasichnyk K, Lopez-Guisa JM, Collins S, Hsu DK, Liu FT, Eddy AA: Galectin-3 preserves renal tubules and modulates extracellular matrix remodeling in progressive fibrosis. Am J Physiol Renal Physiol 2011, 300:F245-F253

24. Lopez-Guisa JM, Cai X, Collins SJ, Yamaguchi I, Okamura DM, Bugge TH, Isacke CM, Emson CL, Turner SM, Shankland SJ, Eddy AA: Mannose receptor 2 attenuates renal fibrosis. J Am Soc Nephrol 2012, 23:236-251

25. Subramanian S, Goodspeed L, Wang S, Kim J, Zeng L, Ioannou GN, Haigh WG, Yeh MM, Kowdley KV, O'Brien KD, Pennathur S, Chait A: Dietary cholesterol exacerbates hepatic steatosis and inflammation in obese LDL receptor-deficient mice. J Lipid Res 2011, 52:1626-1635

26. Lin SL, Castano AP, Nowlin BT, Lupher ML Jr, Duffield JS: Bone marrow Ly6Chigh monocytes are selectively recruited to injured kidney and differentiate into functionally distinct populations. J Immunol 2009, 183:6733-6743

27. Fadok VA, Warner ML, Bratton DL, Henson PM: CD36 is required for phagocytosis of apoptotic cells by human macrophages that use either a phosphatidylserine receptor or the vitronectin receptor (alpha v beta 3). J Immunol 1998, 161:6250-6257

28. Chen L, Willis SN, Wei A, Smith BJ, Fletcher JI, Hinds MG, Colman PM, Day CL, Adams JM, Huang DC: Differential targeting of prosurvival $\mathrm{Bcl}-2$ proteins by their $\mathrm{BH} 3$-only ligands allows complementary apoptotic function. Mol Cell 2005, 17:393-403

29. Fletcher JI, Huang DC: Controlling the cell death mediators Bax and Bak: puzzles and conundrums. Cell Cycle 2008, 7:39-44

30. Willis SN, Adams JM: Life in the balance: how BH3-only proteins induce apoptosis. Curr Opin Cell Biol 2005, 17:617-625

31. Willis SN, Chen L, Dewson G, Wei A, Naik E, Fletcher JI, Adams JM, Huang DC: Proapoptotic Bak is sequestered by Mcl-1 and $\mathrm{Bcl}-\mathrm{xL}$, but not $\mathrm{Bcl}-2$, until displaced by $\mathrm{BH} 3$-only proteins. Genes Dev 2005, 19:1294-1305

32. Viau A, El Karoui K, Laouari D, Burtin M, Nguyen C, Mori K, Pillebout E, Berger T, Mak TW, Knebelmann B, Friedlander G, Barasch J, Terzi F: Lipocalin 2 is essential for chronic kidney disease progression in mice and humans. J Clin Invest 2010, 120: 4065-4076

33. Paragas N, Qiu A, Zhang Q, Samstein B, Deng SX, Schmidt-Ott KM, Viltard M, Yu W, Forster CS, Gong G, Liu Y, Kulkarni R, Mori K, Kalandadze A, Ratner AJ, Devarajan P, Landry DW, D'Agati V, Lin CS, Barasch J: The Ngal reporter mouse detects the response of the kidney to injury in real time. Nat Med 2011, 17:216-222
34. Febbraio M, Hajjar DP, Silverstein RL: CD36: a class B scavenger receptor involved in angiogenesis, atherosclerosis, inflammation, and lipid metabolism. J Clin Invest 2001, 108:785-791

35. Moore KJ, El Khoury J, Medeiros LA, Terada K, Geula C, Luster AD, Freeman MW: A CD36-initiated signaling cascade mediates inflammatory effects of beta-amyloid. J Biol Chem 2002, 277: 47373-47379

36. Stewart CR, Stuart LM, Wilkinson K, van Gils JM, Deng J, Halle A, Rayner KJ, Boyer L, Zhong R, Frazier WA, Lacy-Hulbert A, El Khoury J, Golenbock DT, Moore KJ: CD36 ligands promote sterile inflammation through assembly of a Toll-like receptor 4 and 6 heterodimer. Nat Immunol 2010, 11:155-161

37. Rahaman SO, Lennon DJ, Febbraio M, Podrez EA, Hazen SL, Silverstein RL: A CD36-dependent signaling cascade is necessary for macrophage foam cell formation. Cell Metab 2006, 4:211-221

38. Mossadegh-Keller N, Sarrazin S, Kandalla PK, Espinosa L, Stanley ER, Nutt SL, Moore J, Sieweke MH: M-CSF instructs myeloid lineage fate in single haematopoietic stem cells. Nature 2013, 497:239-243

39. Gow DJ, Sauter KA, Pridans C, Moffat L, Sehgal A, Stutchfield BM, Raza S, Beard PM, Tsai YT, Bainbridge G, Boner PL, Fici G, GarciaTapia D, Martin RA, Oliphant T, Shelly JA, Tiwari R, Wilson TL, Smith LB, Mabbott NA, Hume DA: Characterisation of a novel Fc conjugate of macrophage colony-stimulating factor. Mol Ther 2014 , 22:1580-1592

40. Lenda DM, Kikawada E, Stanley ER, Kelley VR: Reduced macrophage recruitment, proliferation, and activation in colony-stimulating factor-1-deficient mice results in decreased tubular apoptosis during renal inflammation. J Immunol 2003, 170:3254-3262

41. Guo S, Wietecha TA, Hudkins KL, Kida Y, Spencer MW, Pichaiwong W, Kojima I, Duffield JS, Alpers CE: Macrophages are essential contributors to kidney injury in murine cryoglobulinemic membranoproliferative glomerulonephritis. Kidney Int 2011, 80. 946-958

42. Machida Y, Kitamoto K, Izumi Y, Shiota M, Uchida J, Kira Y, Nakatani T, Miura K: Renal fibrosis in murine obstructive nephropathy is attenuated by depletion of monocyte lineage, not dendritic cells. J Pharmacol Sci 2010, 114:464-473

43. Ko GJ, Boo CS, Jo SK, Cho WY, Kim HK: Macrophages contribute to the development of renal fibrosis following ischaemia/reperfusioninduced acute kidney injury. Nephrol Dial Transplant 2008, 23: $842-852$

44. Kitamoto K, Machida Y, Uchida J, Izumi Y, Shiota M, Nakao T, Iwao H, Yukimura T, Nakatani T, Miura K: Effects of liposome clodronate on renal leukocyte populations and renal fibrosis in murine obstructive nephropathy. J Pharmacol Sci 2009, 111:285-292

45. Kluth DC, Ainslie CV, Pearce WP, Finlay S, Clarke D, Anegon I, Rees AJ: Macrophages transfected with adenovirus to express IL-4 reduce inflammation in experimental glomerulonephritis. J Immunol 2001, 166:4728-4736

46. Baranova IN, Vishnyakova TG, Bocharov AV, Leelahavanichkul A, Kurlander R, Chen Z, Souza AC, Yuen PS, Star RA, Csako G, Patterson AP, Eggerman TL: Class B scavenger receptor types I and II and CD36 mediate bacterial recognition and proinflammatory signaling induced by Escherichia coli, lipopolysaccharide, and cytosolic chaperonin 60. J Immunol 2012, 188:1371-1380

47. Leelahavanichkul A, Bocharov AV, Kurlander R, Baranova IN, Vishnyakova TG, Souza AC, Hu X, Doi K, Vaisman B, Amar M, Sviridov D, Chen Z, Remaley AT, Csako G, Patterson AP, Yuen PS, Star RA, Eggerman TL: Class B scavenger receptor types I and II and CD36 targeting improves sepsis survival and acute outcomes in mice. J Immunol 2012, 188:2749-2758

48. Baranova IN, Kurlander R, Bocharov AV, Vishnyakova TG, Chen Z, Remaley AT, Csako G, Patterson AP, Eggerman TL: Role of human CD36 in bacterial recognition, phagocytosis, and pathogen-induced JNK-mediated signaling. J Immunol 2008, 181: $7147-7156$ 
49. Chawla LS, Eggers PW, Star RA, Kimmel PL: Acute kidney injury and chronic kidney disease as interconnected syndromes. N Engl J Med 2014, 371:58-66

50. Parks BW, Black LL, Zimmerman KA, Metz AE, Steele C, MurphyUllrich JE, Kabarowski JH: CD36, but not G2A, modulates efferocytosis, inflammation, and fibrosis following bleomycin-induced lung injury. J Lipid Res 2013, 54:1114-1123

51. Xiong W, Frasch SC, Thomas SM, Bratton DL, Henson PM: Induction of TGF-betal synthesis by macrophages in response to apoptotic cells requires activation of the scavenger receptor CD36. PLoS One 2013, 8:e72772

52. Huen SC, Moeckel GW, Cantley LG: Macrophage-specific deletion of transforming growth factor-betal does not prevent renal fibrosis after severe ischemia-reperfusion or obstructive injury. Am J Physiol Renal Physiol 2013, 305:F477-F484

53. Norris PC, Gosselin D, Reichart D, Glass CK, Dennis EA: Phospholipase A2 regulates eicosanoid class switching during inflammasome activation. Proc Natl Acad Sci U S A 2014, 111:12746-12751

54. Tam VC: Lipidomic profiling of bioactive lipids by mass spectrometry during microbial infections. Semin Immunol 2013, 25:240-248

55. Mancuso P, Standiford TJ, Marshall T, Peters-Golden M: 5Lipoxygenase reaction products modulate alveolar macrophage phagocytosis of Klebsiella pneumoniae. Infect Immun 1998, 66:5140-5146

56. Landgraf SS, Silva LS, Peruchetti DB, Sirtoli GM, Moraes-Santos F, Portella VG, Silva-Filho JL, Pinheiro CS, Abreu TP, Takiya CM, Benjamin CF, Pinheiro AA, Canetti C, Caruso-Neves C: 5Lypoxygenase products are involved in renal tubulointerstitial injury induced by albumin overload in proximal tubules in mice. PLoS One 2014, 9:e107549

57. Eid AA, Gorin Y, Fagg BM, Maalouf R, Barnes JL, Block K, Abboud HE: Mechanisms of podocyte injury in diabetes: role of cytochrome P450 and NADPH oxidases. Diabetes 2009, 58:1201-1211

58. Gangadhariah MH, Luther JM, Garcia V, Paueksakon P, Zhang MZ, Hayward SW, Love HD, Falck JR, Manthati VL, Imig JD, Schwartzman ML, Zent R, Capdevila JH, Pozzi A: Hypertension is a major contributor to 20-hydroxyeicosatetraenoic acid-mediated kidney injury in diabetic nephropathy. J Am Soc Nephrol 2015, 26:597-610

59. Baines RJ, Chana RS, Hall M, Febbraio M, Kennedy D, Brunskill NJ: CD36 mediates proximal tubular binding and uptake of albumin and is upregulated in proteinuric nephropathies. Am J Physiol Renal Physiol 2012, 303:F1006-F1014

60. Iwao Y, Nakajou K, Nagai R, Kitamura K, Anraku M, Maruyama T, Otagiri M: CD36 is one of important receptors promoting renal tubular injury by advanced oxidation protein products. Am J Physiol Renal Physiol 2008, 295:F1871-F1880

61. Susztak K, Ciccone E, McCue P, Sharma K, Bottinger EP: Multiple metabolic hits converge on CD36 as novel mediator of tubular epithelial apoptosis in diabetic nephropathy. PLoS Med 2005, 2:e45

62. Humphreys BD, Xu F, Sabbisetti V, Grgic I, Naini SM, Wang N, Chen G, Xiao S, Patel D, Henderson JM, Ichimura T, Mou S, Soeung S, McMahon AP, Kuchroo VK, Bonventre JV: Chronic epithelial kidney injury molecule-1 expression causes murine kidney fibrosis. J Clin Invest 2013, 123:4023-4035

63. Ichimura $\mathrm{T}$, Asseldonk EJ, Humphreys BD, Gunaratnam L, Duffield JS, Bonventre JV: Kidney injury molecule-1 is a phosphatidylserine receptor that confers a phagocytic phenotype on epithelial cells. J Clin Invest 2008, 118:1657-1668

64. Erwig LP, Henson PM: Clearance of apoptotic cells by phagocytes. Cell Death Differ 2008, 15:243-250

65. Roszer T, Menendez-Gutierrez MP, Lefterova MI, Alameda D, Nunez V, Lazar MA, Fischer T, Ricote M: Autoimmune kidney disease and impaired engulfment of apoptotic cells in mice with macrophage peroxisome proliferator-activated receptor gamma or retinoid X receptor alpha deficiency. J Immunol 2011, 186:621-631

66. Ramirez-Ortiz ZG, Pendergraft WF 3rd, Prasad A, Byrne MH, Iram $\mathrm{T}$, Blanchette $\mathrm{CJ}$, Luster $\mathrm{AD}$, Hacohen $\mathrm{N}$, Khoury JE, Means TK: The scavenger receptor SCARF1 mediates the clearance of apoptotic cells and prevents autoimmunity. Nat Immunol 2013, 14: 917-926

67. Rodriguez-Manzanet R, Sanjuan MA, Wu HY, Quintana FJ, Xiao S, Anderson AC, Weiner HL, Green DR, Kuchroo VK: T and B cell hyperactivity and autoimmunity associated with niche-specific defects in apoptotic body clearance in TIM-4-deficient mice. Proc Natl Acad Sci U S A 2010, 107:8706-8711

68. Sather S, Kenyon KD, Lefkowitz JB, Liang X, Varnum BC, Henson PM, Graham DK: A soluble form of the Mer receptor tyrosine kinase inhibits macrophage clearance of apoptotic cells and platelet aggregation. Blood 2007, 109:1026-1033 